\title{
EFEITO DO CÁLCIO NA HOMEOSTASE DE BROTAÇÕES DE UM CLONE DE Eucalyptus grandis Hill (ex Maiden) SOB CONDIÇÕES DE DEFICIÉNCIA HÍDRICA INDUZIDA in vitro
}

\section{VANDERLEI ANTONIO STEFANUTO}

\author{
Dissertação apresentada à Escola Superior \\ de Agricultura "Luiz de Queiroz", \\ Universidade de São Paulo, para obtenção \\ do título de Mestre em Recursos Florestais, \\ Área de concentração: Recursos Florestais, \\ com opção em Manejo de Florestas de \\ Produção.
}

PIRACICABA

Estado de São Paulo - Brasil

Fevereiro - 2002 


\title{
EFEITO DO CÁLCIO NA HOMEOSTASE DE BROTAÇÕES DE UM CLONE DE Eucalyptus grandis Hill (ex Maiden) SOB CONDIÇÕES DE DEFICIENCIA HÍDRICA INDUZIDA in vitro
}

\author{
VANDERLEI ANTONIO STEFANUTO \\ Biólogo
}

Orientador: Prof. Dr. ANTONIO NATAL GONÇALVES

\begin{abstract}
Dissertação apresentada à Escola Superior de Agricultura "Luiz de Queiroz", Universidade de São Paulo, para obtenção do título de Mestre em Recursos Florestais, Área de concentração: Recursos Florestais, com opção em Manejo de Florestas de Produção.
\end{abstract}

PIRACICABA

Estado de São Paulo - Brasil

Fevereiro - 2002 
Dados Internacionais de Catalogação na Publicação (CIP) DIVISÃO DE BIBLIOTECA E DOCUMENTAÇÃO - ESALQ/USP

\author{
Stefanuto, Vanderlei Antonio \\ Efeito do cálcio na homeostase de brotações de um clone de Eucalyptus \\ grandis Hill ( ex Maiden) sob condições de deficiência hídrica induzida in vitro / \\ Vanderlei Antonio Stefanuto. - - Piracicaba, 2002. \\ 65 p. : il. \\ Dissertação (mestrado) - - Escola Superior de Agricultura Luiz de Queiroz, \\ 2002. \\ Bibliografia. \\ 1. Balanço hídrico 2. Cálcio 3. Eucalipto 4. Fisiologia vegetal 5. Propagação \\ vegetal I. Título
}

CDD 634.9734

"Permitida a cópia total ou parcial deste documento, desde que citada a fonte - $\mathrm{O}$ autor" 


\section{AGRADECIMENTOS}

. A Deus, amigo incondicional.

. Ao Prof. Dr Antonio Natal Gonçalves pela orientação, confiança, amizade.

. À ESALQ/USP (Piracicaba) e ao Departamento de Ciências Florestais e toda à equipe de secretários e assistentes de Departamento (Maria de Fátima Durrer Juliane, Margarete A. Z. Pinese, Alexandre H. Najm, Danilo F. Pereira e Daniel H. dos Santos) pela eficiência e colaboração nos serviços prestados em todos os momentos.

.À UNESP (Rio Claro) por contribuir em muito na minha formação e a todos os amigos de turma - Biologia, 1995.

. Aos amigos Ivo R. Filho e Rogério O. Naressi pela amizade e paciência.

. Ao LARGEA (Laboratório de Reprodução e Genética de Espécies Arbóreas LCF-ESALQ/USP) chefiado pelo Prof. Dr. Paulo Y. Kageyama o qual gentilmente nos disponibilizou o uso de seus equipamentos, e a todo seu grupo de trabalho, com carinho especial às amigas, Andréia M. Moreno e Elza M. Ferraz pela dedicação.

.Ao laboratório de Sementes - (LPV- ESALQ/USP) onde foram realizadas as medidas do potencial hídrico foliar das amostras, com imensa gratidão à Helena M. C. Pescarin Chamma pelo seu auxílio e atenção.

. Ao Prof. Dr. Flávio Tavares (LGN - ESALQ/USP) e toda sua equipe Alessandra, Polé, Jupará, Keila, Dr. Luis H. Gomes "Beto", Felipe e Ana, onde foram desenvolvidos os ensaios de eletroforese em gel de poliacrilamanida. 
- Ao Departamento de Ciências Biológicas (LCB - ESALQ/USP) em especial à Prof $^{a}$ Dr $^{\mathrm{a}}$ Beatriz Apezzato da Glória pelo uso de seu laboratório, materiais de consumo e equipamentos, em especial à técnica responsável do laboratório de anatomia vegetal: Marli K. M. Soares, por sua implacável eficiência e amizade. - Aos Prof. Drs. componentes da banca de qualificação: Adriana P. Martinelli Rodriguez, Marcílio de Almeida e Luis H. Gomes pela grande ajuda prestada. . Aos amigos do coração que me suportaram e me deram força em todos os momentos: Raquel Fernandes - "Raquelzinha", Bibiana Arango, Etienne Grott, Norberto Cornejo (Companheiros de Casa), Raquel Trevizam ("Sandrinha"), Marta Muniz (Sheila Amiga), Ronaldo L. V. Silveira, Fábio Borgatto, Adriana e Telma Hayashi, Ilana U. Bron, Ana Teresa Nery, Irmãs Botturas (Jô, Dani e Bianca), Caroline Egreggio ("bananinha"), Mariana Daher, Alesandra Pitolli, Roselli e Simone Benassi, Marcos Lhano (Baço), Sérgio S. Rocha (Pixuquinho), Sérgio Rangel (Bozó), Marcelo H. Penna (Beliche), Andréa S. Pires.

. Aos amigos do LAFISA: Fábio R. da Silva, Mário Jorge C. dos Santos, Sandra C. Capaldi Arruda, Cantídio Gouvêa, Fernando Grossi, João G. Sacchi, Juliana Viana, Edson Namita, Juliana Bouchardet (Juá), Fabiane Ducatti (Neon), Lúcia H. Basso Menegon, Marília M. C. Cantarelli, Beatriz de Matteo e com carinho especial a grande amiga Flávia Regina Capaldi por sua honestidade, confiança, justiça, sabedoria e existência.

. Às bibliotecárias da ESALQ/USP: Eliana Garcia e Silva Zinsly que sempre se mostram solícitas na hora do desespero.

. A Fundação de Amparo à Pesquisa do Estado de São Paulo (FAPESP) pela concessão da bolsa de Mestrado e pela confiança e sugestões no projeto.

- A todos que, de alguma maneira, contribuíram para a realização desta dissertação.

. E para o ser humano que para mim é a personificação da palavra amigo: Dr. Gustavo Maia Souza. 
Ofereço.....

Aos meus pais, Cido e Cidinha e a minha irmã Valéria que de uma forma indireta me fortaleceram para que eu conseguisse chegar até aqui.

Dedico...

a Deus por ter me presenteado com o Dom da vida, aos meus sobrinhos, William e João Vitor e à minha avó Ditinha, que me enchem de alegria com sua presença. 
"O rio atinge seus objetivos porque aprendeu a contornar obstáculos". (Lao Tse) 


\section{SUMÁRIO}

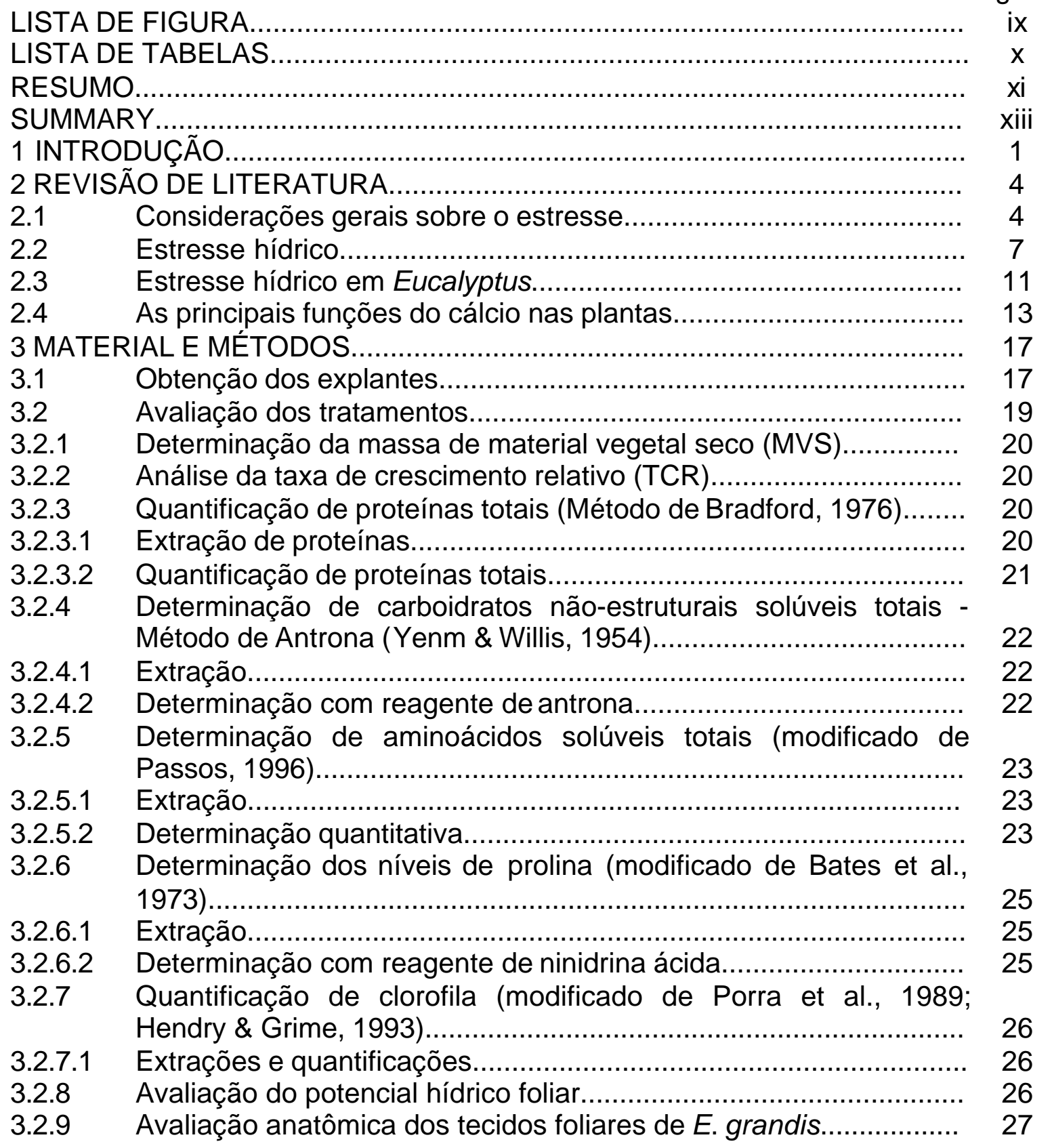




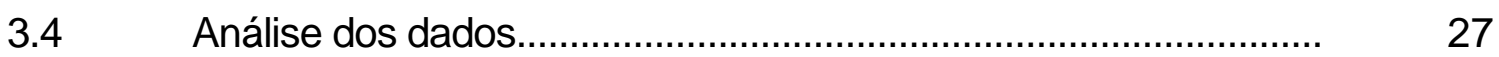

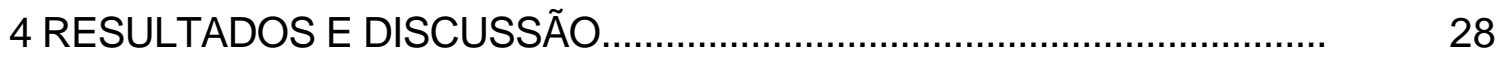

$4.1 \quad$ Considerações gerais................................................................... 28

4.2 Avaliação da taxa de crescimento relativo (T.C.R)........................ 30

$4.3 \quad$ Proteínas solúveis totais............................................................. 31

4.4 Avaliação dos níveis de carboidratos não-estruturais solúveis totais............................................................................... 33

4.5 Avaliação dos níveis de aminoácidos solúveis totais..................... 35

4.6 Avaliação dos teores de prolina..................................................... 37

4.7 Avaliação dos teores de clorofila.................................................... 39

4.7.1 Avaliação dos teores de clorofila a............................................... 39

4.7.2 Avaliação dos teores de clorofila b............................................. 41

4.7.3 Avaliação dos teores de clorofila total............................................ 43

4.8 Avaliação do potencial hídrico foliar.............................................. 45

4.9 Avaliação dos parâmetros relacionados à anatomia foliar............... 47

4.10 Análise de componentes principais............................................... 50

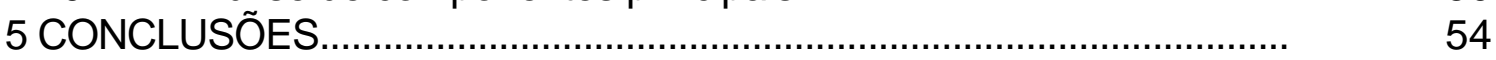

REFERÊNCIAS BIBLIOGRÁFICAS......................................................... 55 


\section{LISTA DE FIGURAS}

Página

1 Esquematização da montagem do experimento...

2 Brotações de E. grandis 21 dias após o retorno às condições normais de crescimento............................................................... 29

$3 \quad$ Taxa de crescimento relativo..................................................... 31

$4 \quad$ Teores de proteínas solúveis totais................................................ 33

$5 \quad$ Teores de carboidratos não-estruturais solúveis............................. 35

$6 \quad$ Teores de aminoácidos solúveis totais.......................................... 37

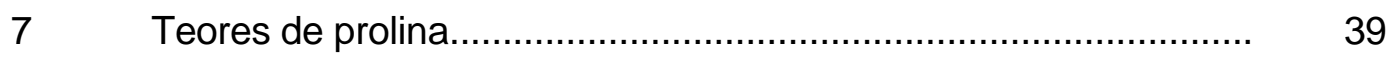

$8 \quad$ Teores de clorofila a.............................................................. 41

$9 \quad$ Teores de clorofila b............................................................ 43

$10 \quad$ Teores de totais de clorofila.................................................... 45

11 Potenciais hídricos foliares do clone de E. grandis ao longo dos três períodos de análise............................................................ 47

12 Micrografias de secções transversais da porção média do limbo foliar de E. grandis.................................................................... 49

13 Micrografias de secções transversais da porção lateral do limbo foliar de E. grandis............................................................. 50

14 Análise de componentes principais após 7 dias sob condições de estresse hídrico induzido por PEG 15\%....................................... 52

15 Análise de componentes principais após 21 dias sob condições de estresse hídrico induzido por PEG 15\%.................................. 53

16 Análise de componentes principais 21 dias após o retorno do material às condições normais de crescimento (JADS básico) Recuperação "recovery". 


\section{LISTA DE TABELAS}

Página

1 Meio de cultura JADS (Correia, 1993)

2 Modificações no meio de cultura JADS líquido (adição de cálcio e PEG) e seus respectivos potenciais hídricos $(\Psi)$ 


\title{
EFEITO DO CÁLCIO NA HOMEOSTASE DE BROTAÇÕES DE UM CLONE DE Eucalyptus grandis Hill (ex Maiden) SOB CONDIÇÕES DE DEFICIÊNCIA HÍDRICA INDUZIDA in vitro
}

\author{
Autor: VANDERLEI ANTONIO STEFANUTO \\ Orientador: Prof. Dr. ANTONIO NATAL GONÇALVES
}

\section{RESUMO}

Este trabalho teve como objetivo verificar os efeitos de diferentes concentrações de cálcio nas respostas de brotações de E. grandis submetido à deficiência hídrica. A hipótese deste trabalho foi a de que o cálcio atua como amenizador dos efeitos causados pela deficiência hídrica. Isto é, aumentando a tolerância (estabilidade) das plantas, retardando as alterações de alguns parâmetros bioquímicos que contribuem para o ajuste osmótico, evitando assim, perdas energéticas excessivas nas sínteses de osmólitos como: açúcares solúveis, aminoácidos solúveis entre outros. Brotações de E. grandis foram cultivadas em meio JADS líquido, suplementadas com 15\% de PEG 6000 e diferentes concentrações de cálcio: 5,0 (controle); 7,5; 10,0; 12,5 e 15,0 mmol.L ${ }^{-1}$. Foram realizadas 4 repetições por tratamento em blocos inteiramente casualizados. As respostas das plantas foram avaliadas de acordo com os seguintes parâmetros: taxa de crescimento relativo, conteúdo de aminoácidos solúveis totais; açúcares solúveis totais; prolina; proteínas totais; teores de clorofila a, b e total; anatomia foliar e potencial hídrico foliar $\left(\psi_{\mathrm{t}}\right)$ As condições 
de cultivo foram: PAR $50 \pm 2 \mu \mathrm{mol} . \mathrm{m}^{-2} \mathrm{~s}^{-1}, 25 \pm 2^{\circ} \mathrm{C}$, e fotoperíodo de 16 horas. As análises foram realizadas aos 7 e 21 dias de cultivo. Então, todo o material vegetal restante foi repicado e transferido para meio JADS básico por 21 dias para a avaliação da recuperação das plantas. O tratamento com PEG, sem cálcio suplementar induziu respostas significativas (Tukey, $p<0,05$ ) em todos os parâmetros bioquímicos em relação ao controle (JADS básico). As análises de componentes principais demonstraram que a dose de cálcio suplementar que mais contribuiu para a homeostase das plantas sob deficiência hídrica foi 7,5 mmol. $\mathrm{L}^{-1}$ de cálcio na forma de $\mathrm{CaCl}_{2}$. 


\title{
THE EFFECTS OF CALCIUM IN THE HOMEOSTASIS OF ONE CLONE OF Eucalyptus grandis Hill (ex Maiden) SHOOTS UNDER WATER DEFECIT CONDITIONS INDUCED in vitro
}

\author{
Author: VANDERLEI ANTONIO STEFANUTO \\ Adviser: Prof. Dr. ANTONIO NATAL GONÇALVES
}

\section{SUMMARY}

The aim of this work was to verify the effects of diferent calcium concentrations in the response of E. grandis shoots to the water deficit. The hypotesis of this work was the calcium acts as a buffer to the effects induced by the water deficit. Thus, increasing the tolerance (estability) of the plants, slowing the changes in some biochemical parameters that contribute to the osmotic adjustment and avoiding excessive energetic losses in the synthesis of osmolites like: soluble sugar, soluble aminoacids amg others. Shoots of E. grandis were cultivated in liquid JADS medium supplemented with 15\% of PEG 600 and different concentration of calcium: 5,0 (control) 7,5; 10,0; 12,5 e 15,0 mmol.L'1. Four replicates were made for treatment in a totally randomized blocks design. The plant responses were evalueted according to the folling variables: relative growth rate, total soluble aminoacid content; total soluble 
sugars; proline content, total soluble proteins, chlorophyll $a$ and b contents, leaf anatomy and leaf water potencial $\left(\psi_{f}\right)$. The growth conditions were: PAR $50 \pm 2$ $\mu$ mol. $\mathrm{m}^{-2} \mathrm{~s}^{-1}, 25 \pm 2^{\circ} \mathrm{C}$ ad 16 hour photoperiod. The analysis were made at the seventh and the $21^{\text {tts }}$ days of culture. Then, all the remainng shoots were transplanted in vitro JADS basic medium for shoots recovery after 21 days of culture. The tratment with PEG 6000 without calcium addition induced signifitive responses (Tukey, $p<0,05$ ) for all biochemical variables in the relation to the control (basic JADS medium). The PCA showed that the supplementar calcium concentration that contributed the most to the shoot homeostais under water deficit was that of $7.5 \mathrm{mmol} . \mathrm{L}^{-1}$ in the form of $\mathrm{CaCl}_{2}$. 


\section{INTRODUÇÃO}

O gênero Eucalyptus possui cerca de 6 milhões de hectares plantados em todo mundo, sendo 3,2 milhões no Brasil, associados principalmente à produção de celulose, carvão, chapas e lenha (Evans, 1992). Esta área está em expansão nas regiões tropicais, as quais apresentam condições térmicas e lumínicas propícias para o crescimento florestal, estando porém, em geral associadas a limitações edáficas e hídricas de diferentes magnitudes (Eldrige et al., 1994).

Dentre as espécies de Eucalyptus plantadas no Brasil, o E. grandis ocupa a maior área (Moura \& Garcia, 2000), uma vez que, tem encontrado condições ideais para seu desenvolvimento sob condições ambientais diversas (Golfari et al., 1978). É, sem dúvida, uma espécie que possui qualidades excelentes, superando qualquer outra em incremento, quando as condições ambientais são adequadas para o seu desenvolvimento.

De acordo com Gonçalves (1995), no Brasil a grande maioria das áreas de reflorestamento ocupadas por Eucalyptus e Pinus estão sobre solos muito intemperizados e lixiviados, portanto, com baixa disponibilidade de nutrientes. Como fator complicante, o atendimento da demanda nutricional das árvores é bastante prejudicado pelos altos índices de deficiência hídrica que ocorrem na maior parte das áreas, como aquelas implantadas na região dos cerrados, onde estão os maiores blocos de reflorestamento com eucaliptos e pinus. 
Este problema pode ser agravado na fase inicial de crescimento das árvores, na qual as exigências hídricas são maiores (Poore \& Fries, 1985; Lima, 1995).

Muito se sabe a respeito do desenvolvimento e reação da parte aérea do eucalipto frente a diferentes condições de clima, solo e de manejo florestal. Por outro lado, são escassos os estudos sobre a influência do cálcio como amenizador do estresse "hídrico" nesse gênero. Barros et al. (1990), conseguiram estabelecer uma relação positiva entre a deficiência de cálcio e a quebra de ponteiras de árvores de eucalipto no campo, em especial durante períodos prolongados de seca.

Tem crescido nas últimas décadas estudos relativos ao metabolismo do cálcio como mensageiro secundário em plantas (Hepler \& Wayne 1985; Alberts, et al. 1997; Malavolta, 1997; 1997; Reddy, 2001). Embora, sua ação específica ainda não tenha sido totalmente descrita, diversas pesquisas 0 indicam como responsável indireto da resposta aos diversos tipos de estresse, inclusive o hídrico (Reddy, 2001).

Ainda que o elemento químico cálcio esteja presente em maior abundância no complexo de troca do solo (Malavolta, 1997), pouco se conhece sob sua ação específica nas plantas quando em deficiência hídrica. Diversos estudos foram e estão sendo feitos no sentido de se conhecer melhor o comportamento eco-fisiológico da espécie em questão, visando uma melhor compreensão dessa dualidade (estresse hídrico versus cálcio).

A hipótese deste trabalho foi a de que o cálcio atua como amenizador dos efeitos causados pela deficiência hídrica. Isto é, aumentando a tolerância (estabilidade) das plantas, retardando as alterações de alguns parâmetros bioquímicos que contribuem para o ajuste osmótico, evitando assim, perdas energéticas excessivas nas sínteses de osmólitos como: açúcares solúveis, aminoácidos solúveis, entre outros.

O objetivo geral desta dissertação foi verificar os efeitos do cálcio no crescimento e restabelecimento de brotações de E. grandis submetidos à 
deficiência hídrica induzida in vitro. Brotações de E. grandis cultivadas in vitro foram submetidas à deficiência hídrica com PEG 6000 a 15\% e diferentes concentrações de cálcio. Após 21 dias de cultivo, as plantas foram transferidas para o meio básico (sem PEG e sem adição de cálcio suplementar) para verificar a capacidade homeostática destas.

Os objetivos específicos consistiram na avaliação de diferentes parâmetros bioquímicos (teores de açúcares, aminoácidos totais, prolina, proteínas totais e clorofila) considerados como indicadores do estresse hídrico, e as suas possíveis relações com diferentes concentrações de cálcio. Ainda dentro dos objetivos específicos foram avaliados: o peso de material vegetal seco; potencial hídrico foliar, e a anatomia foliar dos diferentes tratamentos. 


\section{REVISÃO DE LITERATURA}

\subsection{Considerações gerais sobre o estresse}

O estresse refere-se a um desvio das condições ótimas para a vida, e induz à mudanças e respostas em todos os níveis funcionais do organismo, as quais são reversíveis a princípio mas podem se tornar permanentes (Larcher, 2000).

Espécies ou variedades de plantas diferem em termos de seu ambiente ótimo e de sua suscetibilidade a diferentes tipos de estresse. Alguns trabalhos preferem considerar como estressante apenas aqueles ambientes que danificam as plantas e causam mudanças qualitativas, enquanto outros, consideram que num sistema estressado, a energia consumida aumenta ou a energia potencial do sistema decresce (Lugo \& McCormick ${ }^{1}$, citados por Jones \& Jones, 1992). Uma dificuldade suplementar é que os fatores de estresse normalmente não operam isolados: as interações e co-variações são comuns no ambiente natural.

O estresse pode ter maior efeito durante certas fases do ciclo de vida da planta, como é o caso do estabelecimento da plântula (Jones \& Jones, 1992). A utilização da cultura in vitro para estudos de respostas ao estresse hídrico oferece algumas vantagens no que diz respeito ao controle das condições ambientais, eliminando possíveis interferências de outros tipos de estresse, bem como possibilita uma condição mais homogênea de exposição dos tecidos da planta ao potencial osmótico desejado (Hasegawa et al., 1984).

${ }^{1}$ LUGO, A. E.; McCORMICK, J. F. Influence of environmental stressors upon energy flow in a natural terrestrial ecosystem. In: BERRET, G. W.; ROSENBERG, R. (Ed.) Stress effects on natural ecosystems. New York: Wiley, 1981. p.79-102. 
O estresse ambiental pode induzir padrões similares de resposta ou adaptação em plantas. Alguns dessas respostas podem ser: osmorregulação; síntese de proteínas; acúmulo de solutos compatíveis; redução no crescimento; alterações nas propriedades das membranas celulares; inibição da fotossíntese; aumento da respiração; redução da produção de matéria seca; senescência e abscisão foliar; atuação do ácido abscísico como um "hormônio de estresse", entre outras (Rhodes, 1987; Jones \& Jones, 1992; Larcher, 2000).

De acordo com Hale \& Orcutt (1987), as membranas são provavelmente a primeira linha de defesa contra as mudanças ambientais adversas.

Os aminoácidos (em especial a prolina), e os carboidratos solúveis contribuem para a proteção das biomembranas e das proteínas contra os possíveis danos decorrentes da alta concentração iônica gerada pelo estresse hídrico (Larcher, 2000).

Mesmo na ausência de estresses abióticos, as plantas acumulam prolina. No entanto, a via de acumulação é completamente diferente daquelas operantes durante a resposta ao estresse abiótico (Savouré et al., 1995; Stines et al., 1999).

A seca, direta ou indiretamente, afeta a quantidade ou atividade de enzimas envolvidas na síntese e degradação da prolina. De qualquer forma, o acúmulo de prolina é um efeito secundário em resposta ao estresse hídrico (Stewart et al., 1966). Por outro lado, o acúmulo de prolina pode ser apenas mais um sintoma decorrente do estresse adaptativo (Alfocea \& Laher, 1995).

Plantas bem adaptadas ao ambiente seco ou mesmo salino apresentam uma variedade de mudanças para poderem crescer. A acumulação de prolina é um dos fatores que facilita este ajuste. A síntese de prolina pode ser manipulada pela eliminação do "feedback" de uma enzima reguladora, P5CS ( $\Delta^{1}$-Pirrolina-5-carboxilato sintetase). Além do seu efeito osmoprotetor em condições de estresse, a prolina também pode atuar na degradação de radicais 
livres (Hong et al., 2000), bem como, funcionar como estoque de nitrogênio da célula, compondo o principal estoque energético após o estado de estresse (Delauney \& Verma, 1993; Brurgiére et al., 1999).

Existe uma relação entre o aumento na síntese de prolina e tolerância das plantas ao estresse hiper-osmótico. $O$ acúmulo de prolina parece ser mediado por vias metabólicas ligadas ao ácido abscísico. Isso pode ocorrer tanto de forma dependente quando independente, através de eventos entre a percepção do estresse e a indução da biosíntese de prolina. Em Arabidopsis thaliana, a síntese de um precursor imediato da prolina (P5CS - $\Delta^{1}$ - pirrolina-5-caboxilato sintetase) é aparentemente regulado pela via indireta - mutação do $A B I$ 1, uma proteína serina/treonina fosfatase (Zhang et al., 1997). Similaridades e diferenças entre os eventos sinalizados na regulação dos genes codificados P5C sintetase podem ajudar a elucidar os mecanismos envolvidos no acúmulo de prolina dos tecidos em função do estresse induzido (Hare et al., 1999).

O teor de prolina em brotações de Arabidopsis thaliana L. submetidas ao estresse salino foi inversamente proporcional ao conteúdo relativo de água nos tecidos. A expressão de dois genes reguladores do nível de prolina $\left(\Delta^{1}\right.$-pirolina-5carboxilato sintetase (P5CS) e prolina desidrogenase (ProDH), parece estar sensivelmente ligada a mudanças súbitas no conteúdo de água da célula. Desta forma, a manutenção hídrica celular parece ser regulada pelo acúmulo de prolina nos tecidos (Hayashi et al., 2000).

Simulando os efeitos do estresse salino em Ulva fasciata, Lee \& Liu (1999), constataram que a perda da $\mathrm{Ca}^{2+}$ celular estava associada ao estresse induzido por $\mathrm{NaCl}$, via acumulação de prolina e inibição da atividade da $\mathrm{ProDH}$ (enzima que catabolisa a prolina).

Plantas de feijão (Phaseolus vulgaris L. cv. Contender) sob o efeito de choque osmótico, indicaram que a presença de cálcio suplementar favoreceu o aumento de nutrientes essenciais (ex. potássio), e reduziu sensivelmente a síntese 
de metabólicos orgânicos. Os choques salino e osmótico contribuíram para o aumento de alguns aminoácidos, tanto nas folhas, quanto nas raízes das plantas estudas (Ballester-Fernandez et al., 1997).

Embora prolina e carboidratos sejam dois dos mais importantes solutos orgânicos acumulados em plantas superiores sob condições de estresse hídrico ou salino, nenhuma relação causal foi estabelecida entre a acumulação desses dois metabólicos. Embora, acredita-se que os carboidratos não-estruturais atuem diretamente em enzimas envolvidas no metabolismo da prolina (Laher et al., 1993). A estimulação da síntese de prolina a partir do glutamato sugere a presença de altos níveis de carboidratos como precursores necessários como fonte de $\mathrm{C} \mathrm{e} \mathrm{H}$. O suprimento e metabolismo de carboidratos disponíveis são essenciais para o estímulo de prolina, que tende a ser mais prolongado em folhas com altos níveis de açúcares e amido (Stewart, 1978).

Esses solutos osmoprotetores são amplamente confinados ao citoplasma (incluindo organelas) sendo praticamente ausente nos vacúolos (Matoh et al., 1987).

\subsection{Estresse hídrico}

O estresse hídrico resulta da deficiência hídrica ou do excesso de água no ambiente, sendo o primeiro mais comum. O melhor indicador para a detecção de estresse hídrico é a medida do potencial hidrostático juntamente com o processo de crescimento dependente da turgescência celular, pois o crescimento celular é extremamente sensível a este estresse. Desta forma, o déficit hídrico resulta em uma diminuição do volume celular, um aumento na concentração e uma progressiva desidratação do protoplasto (Hsiao et al. 1976). Não há um processo vital que não seja afetado de alguma forma pelo declínio do potencial hídrico (Larcher, 2000). 
O primeiro efeito da deficiência hídrica é a perda de água ou desidratação da planta (Levitt, 1972). Como conseqüência da perda de água nos tecidos a planta pode apresentar: a) redução no potencial químico ou atividade da água; b) concentração de macromoléculas e solutos de baixo peso molecular; c) alterações nas relações espaciais nas membranas e organelas através da redução do volume e d) redução da pressão hidrostática dentro da célula (Hsiao et al., 1976).

Uma perda acima de $30 \%$ de água causa um aumento gradual da taxa de respiração, que poderá exceder a taxa de fotossíntese desencadeando um processo de inanição na planta, devido ao decréscimo das reservas de carboidratos (Levitt, 1972). Entretanto, estudos recentes em espécies de Populus têm verificado um aumento de síntese de sacarose e outros açúcares solúveis, em resposta ao estresse hídrico, assim como acúmulo de proteínas de estresse hídrico e sacarose sintetase (Pelah et al., 1997).

Após a murcha dos tecidos, o próximo efeito causado pelo estresse hídrico é a perda de proteínas. Esta redução é possivelmente causada pela inibição da formação de protoclorofila, já que sua conversão no cloroplasto não é afetada pelo estresse. Na murcha da planta, detectou-se uma redução de todos os aminoácidos a quantidades muito pequenas, com exceção da prolina que tem sido encontrada, nestes casos, em quantidades maiores que o esperado. Isto sugere uma conexão entre a síntese de prolina e a conhecida produção de amido durante a inanição. Um aumento de prolina e asparagina nas folhas é um dos sintomas de adaptação de trigo de inverno ao estresse hídrico e outras condições desfavoráveis, sua acumulação é maior em plantas mais resistentes. Podem ser detectados aumentos significativos de outros aminoácidos, como fenilalanina, ácido glutâmico, alanina, arginina, histidina, isoleucina e valina. Algumas enzimas apresentam redução, ou até inativação de suas atividades, dependendo da intensidade do estresse a que são submetidas. É o caso da: fosfatase, peptidase, 
peroxidase e desidrogenase. Há redução do conteúdo de RNA, e aumento da atividade da RNAse, assim como, diminuição da síntese de DNA sob condições de estresse hídrico (Levitt, 1972; Hsiao,1976).

Plantas de melancia selvagem (Citrullus lanutus) apresentam uma alta concentração de citrulina em suas folhas sob condições de déficit hídrico. A tolerância à seca relatada em melancias selvagens pode estar relacionada à manutenção do potencial hídrico e a mudanças metabólicas no acúmulo de citrulina - aminoácido não-proteico envolvido na síntese de uréia (Kawasaki et al., 2000).

Arora \& Saradhi (1995) sustentam que o acúmulo de prolina aumenta a resistência de plantas a vários estresses, e resulta em uma maior fixação de carbono. Esta síntese de prolina pode estar relacionada a reações de fotoindução e/ou fotoinativação de enzimas associadas ao catabolismo da prolina. Os trabalhos de Stewart, 1978; e Stewart \& Farher (1980), destacam o importante papel da prolina como soluto osmótico em plantas sob condições de deficiência hídrica. A prolina parece estar relacionada com a manutenção da estabilidade e solubilidade protéica, e atua na regulação do potencial redox nas células (Hare et al., 1998).

Em resposta ao estresse osmótico, as células das plantas aumentam a expressão de alguns genes, ao mesmo tempo em que diminuem a expressão de outros (Zhu et al., 1997). Em geral, esses genes codificam proteínas protetoras que favorecem a acumulação de solutos compatíveis dentro das células (Savouré et al., 1995; Knight et al., 1997). O estresse osmótico também pode elevar a concentração de íons cálcio no citossol das plantas. Este efeito foi observado em Arabdopsis thaliana (Knight et al., 1997; Knight et al, 1998; Sanders et al., 1999).

A análise foliar do teor de clorofila, proteínas e carboidratos (glicose e frutose) em folhas de manona (Ricinus communis) submetidas ao estresse hídrico indicaram elevação no conteúdo desses elementos em função do tamanho da 
folha. A concentração de aminoácidos por unidade de material vegetal seco variou sensivelmente com 0 crescimento das folhas, sendo que durante o estresse hídrico, as concentrações de aminoácidos diminuíram nas folhas jovens de mamona (Shurr et al., 2000).

Outros experimentos têm revelado que o conteúdo de clorofila tende a diminuir durante o estresse hídrico em função da desintegração de membranas devido ao estresse oxidativo em espécies menos tolerantes à seca Moran et al., 1994).

O potencial osmótico das folhas de uva (Vitis vinifera L. cv. Savatiano) sofreu diminuição em plantas sob restrição hídrica. Este fato pode estar relacionado ao acúmulo de solutos - ajuste osmótico ativo. Observou-se também um aumento na concentração de carboidratos, principalmente monossacarídeos. Esse aumento acredita-se estar relacionado à proteção das folhas maduras ao estresse. Por outro lado, não foi quantificado nenhum efeito negativo do acúmulo de carboidratos sob a fotossíntese em folhas jovens de uva sob condições de estresse hídrico (Patakas \& Noitsakis, 2001).

Nepomuceno et al. (1998) sugeriram que a deficiência hídrica induzida por polietilenoglicol 6000 pode ser usada para o monitoramento fisiológico, ou seja, seleção de genótipos resistentes à seca e melhoramento do estoque de germoplasma.

O decréscimo de água no solo diminui o potencial de água na folha e sua condutância estomática, promovendo o fechamento dos estômatos. Esse fechamento bloqueia o influxo de $\mathrm{CO}_{2}$ para as folhas, diminuindo o acúmulo de fotoassimilados, o que implica na redução de produtividade (Ghols et al., 1990). 


\subsection{Estresse hídrico em Eucalyptus}

$\mathrm{Na}$ literatura, encontram-se trabalhos envolvendo algumas espécies de Eucalyptus com estresse hídrico, basicamente trabalhos relacionados à resistência. As espécies mais estudadas são: E. camaldulensis, E. grandis, E. spathulata, E. globulus, E. urophylla, E. maculata, E. viminalis e E. marginata, apontando as possibilidades de utilização destas espécies para coberturas de regiões áridas, além de sua reconhecida utilização na indústria madeireira, de papel, celulose e resinas (Bell et al., 1994).

De acordo com Withers (1978), a tolerância à seca ou a condições de déficit hídrico varia entre as espécies de eucalipto. Algumas espécies não apresentam qualquer capacidade, ou apresentam baixa capacidade no controle das perdas de água por transpiração e, desta forma, apresentam restrita tolerância às condições de déficit hídrico. Esta característica provavelmente é importante na restrição dos limites de ocorrência natural destas espécies, ou seja, na restrição dos habitats onde tais espécies apresentam condições de sobreviver.

Quanto ao grau de resistência à seca, Goes (1962) propõe que as espécies de eucalipto podem ser classificadas como resistentes (ex. E. camaldulensis), medianamente resistentes (ex. E. grandis) e pouco resistentes ( $E$. citriodora).

A maioria das espécies de eucalipto desenvolveu mecanismos fisiológicos de adaptação a condições de déficit hídrico, ou seja, mecanismos de restrição do consumo de água nos períodos do ano quando a disponibilidade de água no solo é menor. Entre estes mecanismos, podem ser incluídos, por exemplo: a) o desenvolvimento de tecido foliar endurecido; b) o alinhamento vertical das folhas; c) o "lignotuber", d) melhor eficiência no fechamento dos estômatos em resposta a aumento do estresse hídrico; e) eficiência fotossintética em condições de disponibilidade de água, entre outros (Jacobs, 1955; Pryor, 1976; Florence, 1981). Em comunidades naturais, essas adaptações são 
importantes para a sobrevivência, conferindo vantagem que permite melhor produção em condições onde a deficiência hídrica prevalece (Turner, 1986).

De acordo com Dye (1996), árvores de Eucalyptus grandis suportam potenciais osmóticos de até $-2 \mathrm{MPa}$ antes de apresentarem sintomas severos causados pela deficiência hídrica.

Segundo informações obtidas por Lima (1997), o E. grandis apresenta um mecanismo de melhor uso e eficiência de água sob condições de deficiência hídrica, evitando assim um aumento na desidratação das folhas.

Os mecanismos que previnem a tensão hídrica interna das plantas quase sempre são incompatíveis com a produção vegetal. Algumas espécies, no entanto, são capazes de suportar deficiência hídrica acentuada, sem que haja fechamento total dos estômatos, permitindo que a fixação de $\mathrm{CO}_{2}$ ocorra, mesmo sob variações acentuadas no conteúdo hídrico da folha (Levitt, 1972).

A folha, assim como o caule e a raiz, compreendem três sistemas principais de tecidos: o sistema dérmico, constituído da epiderme superior e inferior, o tecido fundamental, constituído de mesofilo e o sistema vascular, consistindo de feixes vasculares formando nervuras (Cutter, 1986).

Souza et al., (1999) verificaram que a deficiência hídrica induzida pode alterar significativamente a estrutura anatômica das folhas de E. camaldulensis. O colapso das células, atraso na diferenciação dos tecidos, desorganização do feixe vascular e da epiderme e alterações do mesofilo constituem sintomas típicos.

O conhecimento das relações hídricas auxiliará na definição dos espaçamentos mais adequados para as espécies florestais, visando à utilização desses fatores de maneira mais desejável para cada situação de modo a aumentar a eficiência produtiva das plantas (Leles et al., 1997).

Seguindo as sugestões de Reis \& Hall (1996), o gênero Eucalyptus pode ser utilizado para compor planos de reflorestamento em várias regiões do Estado de São Paulo que apresentam condições desfavoráveis de água no solo, 
uma vez que a produtividade florestal esta relacionada com a ótima interação entre água-nutriente dentro de um ecossistema como aponta o trabalho de Nambiar (1990/91).

Diversos estudos indicam que a restrição hídrica no gênero Eucalyptus tem afetado de forma direta e indireta o estabelecimento e crescimento das árvores (Honesett, 1996; Osório et al., 1998; Benyon, 2000).

\subsection{As principais funções do cálcio nas plantas}

O cálcio tem muitas funções no crescimento e desenvolvimento vegetal. $\mathrm{O}$ atraso no amadurecimento dos frutos e na senescência e abscisão foliar; a melhoria na qualidade dos frutos e hortaliças; a alteração na resposta geotrópica, na fotossíntese e em outros processos como: divisão celular, movimentos citoplasmáticos e aumento do volume celular são apenas algumas das funções do cálcio nas plantas (Malavolta et al., 1997). O cálcio também está diretamente envolvido nas funções do citoesqueleto (Feijo et al., 1995; Malho \& Trewavas, 1996).

A fosforilação protéica em plantas pode ser regulada pelo $\mathrm{Ca}^{2+}$ sob concentrações fisiológicas sendo a última parte dessa regulação mediada pela calmodulina (Marmé, 1988).

Poovaiah \& Reddy (1987), comentam que devido à semelhança de raio iônico, outros cátions poderiam substituir os sítios de ligação do cálcio, mas eles não estariam capacitados para substituir o cálcio em uma de suas principais funções, ou seja, a de estabilizador da membrana.

O cálcio encontra-se principalmente nas folhas das plantas e, como não se transloca, é detectado em maiores quantidades nas folhas velhas. A maior parte do cálcio aparece na lamela média das paredes celulares, como sal de compostos pécticos. Surge também nos vacúolos celulares, sob a forma de cristais insolúveis. A maior importância do cálcio para a planta é como nutriente, 
sendo também indispensável nos pontos de crescimento (meristemas) onde se processa a divisão mitótica contínua, bem como no desenvolvimento radicular, atuando nos processo de (i) alongamento celular; (ii) desintoxicação dos íons hidrogênio e (iii) divisão celular. Os cátions de cálcio se combinam com grupos carboxílicos do ácido péctico dando origem ao pectato de cálcio que, juntamente com o pectato de magnésio, formam a lamela média da parede celular, responsável pela ligação de células adjacentes (Mascarenhas, 1977).

Várias desordens fisiológicas como o "buraco amargo" (bitter pit) da maçã, a podridão estilar ou fundo preto do tomate, o coração negro do tomate e o coração negro ôco da batata estão relacionados com o baixo teor de $\mathrm{Ca}^{2+}$ nesses tecidos. O aumento no nível de cálcio em geral diminui a ocorrência ou gravidade dessas desordens. Todas essas desordens têm sintomas similares de encharcamento dos tecidos, característica da perda da integridade da membrana e aumento do escoamento (Malavolta et al., 1997).

A concentração dos elementos nas plantas varia com a idade, parte da planta, espécie, enraizamento ou tipo de solo. Por exemplo, em média a concentração de $\mathrm{Ca}^{2+}$ no tecido seco gira em torno de $0,5 \%$ e no solo de $0,43 \%$ (Hale \& Orcutt, 1987).

Virtualmente, todos os estudos com auxina, giberilinas, citocininas, gravidade entre outros, têm usado concentrações de cálcio entre $-0,1$ e $10 \mathrm{mM}$, uma quantidade centenas de vezes maior do que a célula necessita (Hepler \& Wayne, 1985).

Estudando quatro clones (três de E. grandis e um E.grandis x $E$. urophylla) em condições de viveiro por 0; 15; 30; 45; 60; 75 e 90 dias, Camargo (1997) constatou que as folhas apresentaram uma tendência de aumento no teor de cálcio em função da idade, enquanto o caule função inversa, sendo que as raízes, poucas variações sofreram no decorrer dos estágios. 
Estímulos externos (luz, gravidade, mecânicos) e internos (hormônios) atuam sobre os mecanismos transportadores de $\mathrm{Ca}^{2+}$ modificando seu nível no citoplasma: o estímulo é uma mensagem que é conduzida pelo $\mathrm{Ca}^{2+}$ como "mensageiro secundário". Quando a célula "percebe" a mensagem, o $\mathrm{Ca}^{2+}$ é descarregado dos seus reservatórios, como o apoplasto, mitocôndrias e retículo endoplasmático no citossol (Malavolta et al., 1997).

A concentração de $\mathrm{Ca}^{2+}$ no citossol é baixa quando comparada com a do vacúolo e de outras organelas. Tal concentração baixa é garantida pela ação de ATPases transportadoras de cálcio localizadas no plasmalema, as quais retiram $\mathrm{Ca}^{2+}$ do citossol. A atividade dessas ATPases, por sua vez, é controlada por proteínas reguladoras, as calmodulinas $\left(\mathrm{Ca}^{2+}\right)$, que se combinam com o $\mathrm{Ca}^{2+}$. $\mathrm{O}$ aumento na concentração de $\mathrm{Ca}^{2+}$ no citossol ativa a calmodulina que, por sua vez, ativa numerosas enzimas, o que leva a uma resposta por parte da planta. A calmodulina ativa também a Ca-ATPase que bombeia o cálcio de volta aos seus reservatórios. Com isso, o $\mathrm{Ca}^{2+}$ no citossol cai e diminui a ativação enzimática efetuada pela calmodulina (Trewavas \& Knight, 1994, Malavolta et al., 1997; Alberts et al., 1997).

A observação da resposta metabólica de células de eucalipto e girassol sob estresse hidrodinâmico mostrou que o cálcio do citossol funciona como um mensageiro de segunda ordem, mediando o sinal do estresse hidrodinâmico dentro do metabolismo que induz o decréscimo da taxa de respiração (Takeda et al., 1998).

De acordo com a revisão apresentada por Mallhó et al. (1999), ondas de cálcio são geradas em pontos específicos da célula (vacúolo, cloroplasto, mitocôndrio e retículo endoplasmático rugoso) em função de sinais externos (p. ex. choque hiper-osmótico) ativando a síntese de proteínas específicas.

Os estudos de Mengel \& Kirkby (1982) e Zekri (1995) mostraram que a deficiência hídrica pode reduzir as concentrações de cálcio nas plantas o que 
também podem causar uma deficiência nutricional. Todavia, o trabalho de AbdelBasset (1998) indicou que a adição de cálcio ao substrato das plantas reduz os efeitos da deficiência hídrica, promovendo o aumento de peso seco, conteúdo de água e clorofila. Ballester-Fernandez et al. (1997) também verificaram um incremento do crescimento de plantas sob estresse hídrico após adição de $\mathrm{Ca}^{2+}$.

Barros et al. (1990) em suas pesquisas sugeriram que a seca de ponteiros, freqüentemente observada em árvores durante períodos de seca prolongada no Brasil, parece estar ligada à deficiência de cálcio.

Plantas de Coffea arabica sob condições de deficiência de $\mathrm{Ca}^{2+}$ apresentaram redução no nível de clorofila e proteínas solúveis (Ramalho \& Nunes, 1999; Ramalho, et. al., 1995).

Embora de difícil constatação, o excesso de cálcio pode ser observado principalmente através da clorose, mais comum em vários gêneros de frutíferas e plantas ornamentais (Bergmann, 1992).

Pesquisas durante as duas últimas décadas têm deixado claro que o $\mathrm{Ca}^{2+}$ atua como mensageiro intracelular acoplado a diversos sinais extracelulares para respostas específicas. Existem descritos quatro grupos de proteínas sensíveis ao cálcio nas plantas: (1) proteínas-quinases dependentes de cálcio; (2) calmodulinas; (3) outras proteínas associadas ao cálcio com motivos "EF-hand" e (4) proteínas associadas ao cálcio sem motivos 'EF-hand". De forma indireta, somente as do grupo 1 e 2 estão relacionadas à indução de genes reguladores do estresse (Reddy, 2001).

Embora, os mecanismos pelos quais o cálcio atua na redução dos efeitos do estresse não sejam bem conhecidos, Reddy (2001) sugere que $\mathrm{Ca}^{2+}$ serve como mensageiro em muitos processos de crescimento e desenvolvimento em respostas ao estresse biótico e abiótico. 


\section{MATERIAL E MÉTODOS}

\subsection{Obtenção dos explantes}

Brotações de um clone de Eucalyptus grandis pertencente ao laboratório de Fisiologia das Árvores (LAFISA), Departamento de Ciências Florestais -ESALQ/USP foram utilizados no presente estudo. No processo de obtenção do número de explantes suficientes para a montagem do experimento, 96 conjuntos de brotações passaram por 6 subcultivos (21 dias) em meio de cultura JADS (Correia, 1993), suplementados com $0,5 \mathrm{mg} / \mathrm{L}^{-1}$ de BAP, $1 \mathrm{mg} / \mathrm{L}^{-1}$ de AIA, $3 \%$ de sacarose e $0,5 \%$ de ágar (Tabela 1 ).

Tabela 1. Meio de cultura JADS (Correia, 1993).

\begin{tabular}{|c|c|c|c|}
\hline Macronutrientes & $\mathrm{mg} \cdot \mathrm{L}^{-1}$ & Aditivos & $\mathrm{mg} \cdot \mathrm{L}^{-1}$ \\
\hline & & Ácido nicotínico & 0,5 \\
\hline $\mathrm{NH}_{4} \mathrm{NO}_{3}$ & 324,0 & Piridoxina & 0,5 \\
\hline $\mathrm{KNO}_{3}$ & 809,0 & Tiamina & 5,0 \\
\hline $\mathrm{KH}_{2} \mathrm{PO}_{4}$ & 408,0 & Meso inositol & 100,0 \\
\hline $\mathrm{Ca}\left(\mathrm{NO}_{3}\right)_{2} \cdot 4 \mathrm{H}_{2} \mathrm{O}$ & 1181,0 & Arginina & 7,0 \\
\hline \multirow[t]{3}{*}{$\mathrm{MgSO}_{4} .7 \mathrm{H}_{2} \mathrm{O}$} & 739,5 & Glutamina & 146,0 \\
\hline & & Cisteína & 5,0 \\
\hline & & Pantotenato de cálcio & 2,4 \\
\hline Micronutrientes & $\mathrm{mg} \cdot \mathrm{L}^{-1}$ & Outros & $\left(g \cdot L^{-1}\right)$ \\
\hline $\mathrm{FeSO}_{4} .7 \mathrm{H}_{2} \mathrm{O}$ & 55,6 & Sacarose & 20,0 \\
\hline $\mathrm{Na}_{2} \mathrm{EDTA}$ & 74,5 & Ágar & 6,0 \\
\hline $\mathrm{MnSO}_{4} \cdot 7 \mathrm{H}_{2} \mathrm{O}$ & 16,9 & $6 \mathrm{BAP}$ & 0,005 \\
\hline $\mathrm{Na}_{2} \mathrm{MoO}_{4} \cdot 2 \mathrm{H}_{2} \mathrm{O}$ & 4,32 & AIA & 0,001 \\
\hline $\mathrm{CuSO}_{4} .5 \mathrm{H}_{2} \mathrm{O}$ & 1,25 & & \\
\hline $\mathrm{CoCl}_{2} \cdot 6 \mathrm{H}_{2} \mathrm{O}$ & 0,25 & & \\
\hline $\mathrm{H}_{3} \mathrm{BO}_{3}$ & 3,1 & & \\
\hline
\end{tabular}


As condições de crescimento das brotações foram: temperatura de 25 $\pm 2^{\circ} \mathrm{C}$, fotoperíodo de 16 horas e PAR (radiância fotossinteticamente ativa) de 50 $\pm 2 \mu \mathrm{mol} . \mathrm{m}^{-2} \mathrm{~s}^{-1}$ em sala climatizada.

$\mathrm{Na}$ última repicagem, antes da montagem do experimento, todo material foi transferido para o meio de cultura JADS líquido. Neste caso, para a sustentação das brotações foram usadas mantas acrílicas recortada no mesmo diâmetro dos frascos. O tamanho dos explantes foram padronizados.

Após 21 dias de cultivo em meio JADS líquido, as brotações foram transferidas simultaneamente para os tratamentos com PEG 6000 a $15 \%$ e diferentes concentrações de cálcio, como descrito na Tabela 2.

Tabela 2. Modificações no meio de cultura JADS líquido (adição de cálcio e PEG) e seus respectivos potenciais hídricos ( $\Psi)$.

\begin{tabular}{|c|c|c|c|c|}
\hline \multirow[b]{2}{*}{$\begin{array}{c}\text { Tratamento } \\
\mathrm{s}\end{array}$} & \multicolumn{4}{|c|}{ Modificações no meio de cultura JADS líquido } \\
\hline & $\begin{array}{c}\text { Adição de PEG } \\
6000\end{array}$ & $\begin{array}{l}\text { Adição de } \mathrm{Ca}^{2+} \text { na } \\
\text { forma de } \mathrm{CaCl}_{2} \\
\left(\mathrm{mmol} . \mathrm{L}^{-1}\right)\end{array}$ & $\begin{array}{l}\text { Potenciais } \\
\text { hídricos } \\
\text { (MPa) }\end{array}$ & $\begin{array}{c}\text { Cálcio } \\
\text { Total } \\
\left(\mathrm{mmol.L}{ }^{-1}\right)\end{array}$ \\
\hline $\mathrm{C}_{\mathrm{T}}$ & 0 & 0 &,- 16 & 5,0 \\
\hline $\mathrm{T}_{1}$ & $15 \%$ & 0 & $-0,9$ & 5,0 \\
\hline $\mathrm{T}_{2}$ & $15 \%$ & 2,5 & $-0,79$ & 7,5 \\
\hline $\mathrm{T}_{3}$ & $15 \%$ & 5 & $-0,81$ & 10,0 \\
\hline $\mathrm{T}_{4}$ & $15 \%$ & 7,5 & $-1,05$ & 12,5 \\
\hline$T_{5}$ & $15 \%$ & 10 & $-1,04$ & 15,0 \\
\hline
\end{tabular}

Os potenciais hídricos dos diferentes meios de cultura foram medidos psicrometricamente em câmaras modelo C-52 Wescor, acopladas a um microvoltímetro - Wescor modelo HR-33T, operando em modulo "Ponto de Orvalho".

Visando conhecer a capacidade do sistema retornar a sua condição normal após ter sofrido pertubação - homeostase (Kauffman, 1993), ao final de 21 dias de cultivo sob deficiência hídrica, parte do material em cada tratamento foi repicado e transferido para o meio de cultura JADS básico (controle), permanecendo por mais 21 dias. 
Todos os ensaios foram realizados em blocos inteiramente casualizados com 4 repetições por tratamento e 4 grupos de brotações por frasco contendo $40 \mathrm{~mL}$ do meio de cultura (Figura 1).

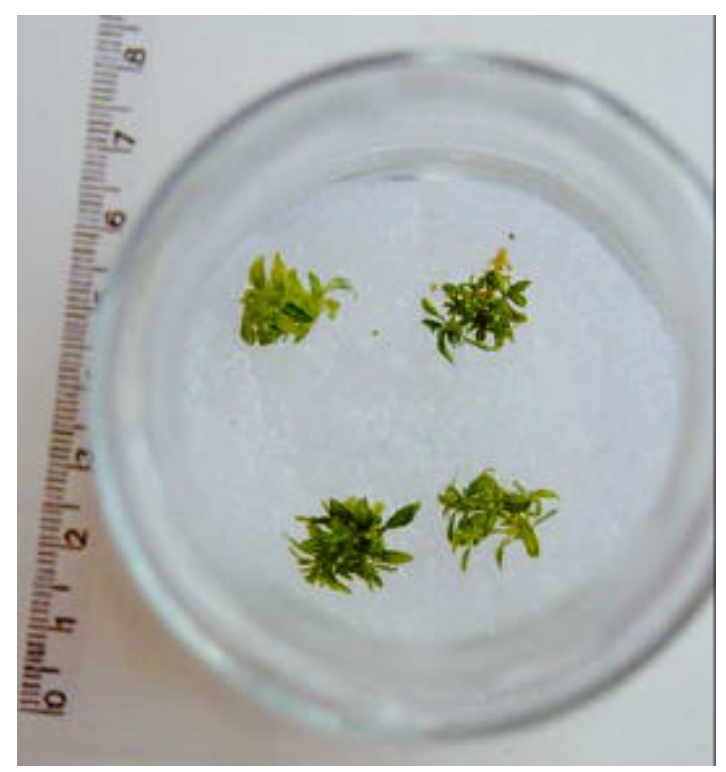

Figura 1 - Esquematização da montagem do experimento - frasco contendo 4 grupos de brotações do clone de E. grandis estudado.

\subsection{Avaliação dos tratamentos}

No período de cultivo com deficiência hídrica e diferentes concentrações de $\mathrm{Ca}^{2+}$, os tratamentos foram avaliados aos 7 e 21 dias. No período de recuperação, o material foi avaliado ao final de 21 dias de cultivo.

Foram analisados os seguintes parâmetros: (i) massa de material vegetal seco; (ii) TCR (taxa de crescimento relativo); (ii) proteínas totais; (v) carboidratos não-estruturais solúveis totais; (v) aminoácidos solúveis totais; (vi) prolina; (vii) clorofilas ( $\mathrm{a}$, b e total); (viii) potencial hídrico foliar e (IX) e anatomia foliar. 
Todas as amostragens foram feitas em triplicatas, assim como a leitura de cada amostra.

\subsubsection{Determinação da massa de material vegetal seco (MVS)}

A cada período de amostragem, analisou-se inicialmente o massa do material vegetal fresco (MVF). Em seguida o material foi submetido ao processo de secagem em estufa a uma temperatura de $60^{\circ} \mathrm{C} \pm 5,0^{\circ} \mathrm{C}$ por um período nunca inferior a 48 horas até que se atingisse uma massa seca constante.

\subsubsection{Análise da taxa de crescimento relativo (TCR)}

A taxa de crescimento relativo foi obtida através da seguinte equação modificada do trabalho de Hunt (1982):

Taxa de crescimento relativo $=\underline{\ln \text { PMVS }(X n)-\operatorname{InPMVS}\left(X_{0}\right)} \cdot 100$

$$
T(X n)
$$

Onde: $\mathrm{In}=$ logaritmo Neperiano; PMVS $(\mathrm{Xn})$ = massa da matéria vegetal seca média tomada ao final de cada amostragem; PMVS $\left(X_{0}\right)=$ massa da matéria vegetal seca média tomadas no início da instalação do experimento e $\mathrm{T}(\mathrm{Xn})=$ Tempo de cultivo (7 ou 21 dias).

\subsubsection{Quantificação de proteínas totais (Método de Bradford, 1976)}

\subsubsection{Extração de proteínas}

Preparo da solução de extração:

Em um bequer foram adicionados: $4 \mathrm{~mL}$ de tampão tris- $\mathrm{HCl} \mathrm{pH} 6,8$ foram adicionados a $1,6 \mathrm{~mL}$ de $\beta$-mercaptoetanol; $6,4 \mathrm{~mL}$ de SDS-10\% (P/V); 6,4mL de glicerol; 3,2mL de DMSO; 1-3 g de PVP 40; 10,4 mL de água destilada deionizada. A solução foi colocada sob agitação magnética por $45 \mathrm{~min}$. 
Amostras de $\pm 500 \mathrm{mg}$ (material vegetal fresco) de brotações de $E$. grandis foram coletadas e maceradas em gral de porcelana com $4 \mathrm{~mL}$ da solução de extração para cada tratamento. Após maceração, o material vegetal permaneceu por $1 \mathrm{~h}$ à temperatura ambiente. Em seguida a mistura foi aquecida até ferver por $3 \mathrm{~min}$. Após resfriamento, as amostras foram centrifugadas por 300 s a uma velocidade de $13.444,14 \mathrm{~g}$, obtendo-se desta forma, o extrato bruto. $\mathrm{O}$ sobrenadante foi coletado com auxílio de micropipeta e utilizado para a quantificação do teor de proteínas totais.

\subsubsection{Quantificação de proteínas totais}

Preparo da solução estoque de BSA (albumina bovina):

Pesou-se 0,5 mg de BSA / $\mathrm{mL}$ de $\mathrm{NaCl} 0,5 \mathrm{M}$.

Preparo da solução de Coomassie Brilliant Blue G 250:

Em balão volumétrico de 1L, foram dissolvidos $100 \mathrm{mg}$ de Coomassie Brilliant Blue em $50 \mathrm{~mL}$ de etanol. A solução foi agitada vigorosamente e, lentamente foram adicionados $100 \mathrm{~mL}$ de ácido fosfórico concentrado. O volume foi completado para $1 \mathrm{~L}$ com água destilada deionizada. A solução foi posteriormente filtrada em papel de filtro Whatman $n^{\circ} 1$.

Preparo da curva analítica de calibração e leitura das amostras:

A curva analítica de calibração foi realizada em triplicata com os seguintes padrões: $0 ; 10 ; 20 ; 40 ; 60 ; 80 ; 100 ; 120 ; 140 ; 160 ; 180$ e 200mg de albumina. $L^{-1}$.

Adicionou-se o volume de $500 \mu \mathrm{L}$ de solução $\mathrm{NaCl}$ 0,5M, sendo que o volume final foi completado para $5 \mathrm{~mL}$ com a solução de Coomassie. A curva analítica de calibração foi estabelecida a 595nm em espectrofotômetro e com ela obteve-se a equação da reta através da qual foi possível a determinação do teor de proteínas totais em cada tratamento na forma de $\mathrm{mg}$ de proteínas. $\mathrm{g}^{-1}$ de material vegetal fresco. Para a quantificação dos teores de proteínas totais nas 
amostras, adicionou-se $50 \mu \mathrm{L}$ de amostra a $4,5 \mathrm{~mL}$ de solução de Coomassie e procedeu-se à leitura em espectrofotômetro a 595nm.

\subsubsection{Determinação de carboidratos não-estruturais solúveis totais - Método de Antrona (Yenm \& Willis, 1954)}

\subsubsection{Extração}

Foram pesadas aproximadamente $500 \mathrm{mg}$ (material vegetal fresco) de brotações de E. grandis em todos os tratamentos. A maceração do material procedeu-se em gral de porcelana com a adição de $10 \mathrm{~mL}$ de etanol $80 \%(\mathrm{~V} / \mathrm{V})$. Esse extrato foi filtrado em papel de filtro Whatman $n^{\circ} 1$ sendo o volume recolhido mantido em estufa à vácuo a $45^{\circ} \mathrm{C}$, até a evaporação total do álcool (aproximadamente 17h). Após a evaporação, as amostras foram resuspendidas em $30 \mathrm{~mL}$ de água destilada e deionizada.

\subsubsection{Determinação com reagente de antrona}

Preparo do reagente de Antrona:

A $5 \mathrm{~mL}$ de água destilada e deionizada foram adicionados $45 \mathrm{~mL}$ de ácido sulfúrico concentrado e $100 \mathrm{mg}$ de antrona. A solução foi deixada por 30 min. em temperatura ambiente, sendo agitada ocasionalmente para obter-se a clarificação da mesma.

Preparo da curva analítica de calibração de Glicose:

Foi preparada uma curva analítica de calibração em triplicata com os seguintes padrões de glicose: $0 ; 25 ; 50 ; 75 ; 100 ; 125 ; 150 ; 175$ e 200mg de glicose. $\mathrm{L}^{-1}$. De cada padrão, pipetou-se $1 \mathrm{~mL}$. Em seguida foram adicionados $7 \mathrm{~mL}$ do reagente de antrona. A solução foi agitada e aquecida em água fervente por $10 \mathrm{~min}$. Após resfriamento em gelo, procedeu-se à leitura a $625 \mathrm{~nm}$ em 
espectrofotômetro obtendo-se a curva analítica de calibração e a equação da reta que melhor se adaptou aos pontos obtidos. Procedeu-se então à leitura das amostras, e com a equação obtida mediante a curva analítica de calibração, foi possível a estimativa da concentração de carboidratos não-estruturais totais (em $\mathrm{mg}$ de glicose. $\mathrm{g}^{-1}$ de material vegetal fresco) para cada tratamento proposto.

\subsubsection{Determinação de aminoácidos solúveis totais (Modificado de Passos, 1996)}

\subsubsection{Extração}

Aproximadamente $300 \mathrm{mg}$ (material vegetal fresco) de brotações de E. grandis para cada tratamento foram maceradas em gral de porcelana contendo $10 \mathrm{~mL}$ de MCA (met/clor/água - 12:5:3). Esta solução foi submetida à centrifugação por $900 \mathrm{~s}$ a uma velocidade de $3 \cdot 360,70 \mathrm{~g}$. De cada tratamento foi retirada uma alíquota de $3 \mathrm{~mL}$, que posteriormente foi acrescida de água destilada deionizada e clorofórmio na mesma proporção. Da mistura bifásica formada em cada um dos tubos, foi coletado apenas $1 \mathrm{~mL}$ da camada superficial para a continuidade do processo. A camada mais densa foi descartada - clorofórmio.

\subsubsection{Determinação quantitativa}

Preparo dos reagentes:

A. Hidrindantina: Foram dissolvidos $4 \mathrm{~g}$ de ninidrina em $100 \mathrm{~mL}$ de água destilada e deionizada a $90^{\circ} \mathrm{C}$. Em ato contínuo, foram dissolvidos $4 \mathrm{~g}$ de ácido ascórbico em $20 \mathrm{~mL}$ de água, a $40^{\circ} \mathrm{C}$. A solução de ninidrina foi colocada sob agitação magnética e em seguida adicionou-se a solução de ácido ascórbico. $\mathrm{A}$ cristalização da hidrindantina iniciou-se imediatamente. Sem mais aquecimento, deixou-se o processo ocorrer por mais 40 min. A solução foi deixada para resfriar 
à temperatura ambiente. $A$ filtragem deu-se em papel de filtro Whatman $n^{\circ} 1 . A$ secagem da hidrindantina foi feita em estufa a $50^{\circ} \mathrm{C}$ por aproximadamente $15 \mathrm{~h}$.

B. Tampão acetato: Adicionou-se $160 \mathrm{~g}$ de $\mathrm{NaOAc}$ anidro a $200 \mathrm{~mL}$ de água destilada e deionizada. Após a dissolução, foi adicionado ao conteúdo $50 \mathrm{~mL}$ de ácido acétido glacial. $\mathrm{O} \mathrm{pH}(5,5)$ foi ajustado e o volume completado com água destilada e deionizada para $1 \mathrm{~L}$.

C. Reagente de Ninidrina: Em um bequer foi adicionado $62,5 \mathrm{~mL}$ de tampão acetado (4N e pH 5,5), 187,5mL de éter monometílico de etilenoglicol, $500 \mathrm{mg}$ de ninidrina e $75 \mathrm{mg}$ de hidrindantina. A dissolução procedeu-se sob agitação magnética e temperatura constante.

Procedimentos:

Alíquotas de $1 \mathrm{~mL}$ das amostras foram adicionadas a $2 \mathrm{~mL}$ do reagente de ninidrina. Os tubos foram tapados e agitados manualmente para a obtenção de uma mistura.

As amostras foram colocadas em banho-maria por 15min. Em seqüência foi adicionado a cada tubo $5 \mathrm{~mL}$ de etanol $50 \%$. Os tubos foram resfriar em banho de gelo e agitados manualmente. A leitura foi realizada a uma absorbância de 570nm.

Preparo da curva analítica de calibração de leucina:

Foi preparada uma curva analítica de calibração com os seguintes padrões de leucina: $0 ; 25 ; 50 ; 75 ; 100 ; 125 ; 150 ; 175$ e 200mg de leucina. $L^{-1}$. De cada padrão foi pipetado $1 \mathrm{~mL}$. Na seqüência foram adicionados $2 \mathrm{~mL}$ do reagente de ninidrina em cada triplicata. A solução foi agitada e aquecida em água fervente por 15 minutos e posteriormente acrescida de $5 \mathrm{~mL}$ de etanol $50 \%$. Após resfriamento em banho de gelo, procedeu-se a leitura a 570nm. Através da equação obtida mediante a curva analítica de calibração, foi possível estimar a 
concentração de aminoácidos solúveis totais ( $\mu$ g de aminoácidos solúveis totais / $\mathrm{g}$ de material vegetal fresco).

\subsubsection{Determinação dos níveis de prolina (modificado de Bates et al., 1973)}

\subsubsection{Extração}

Foram pesados cerca de $300 \mathrm{mg}$ (material vegetal fresco) de brotações

de E. grandis para cada tratamento. Os materiais foram macerados em gral de porcelana em $10 \mathrm{~mL}$ de solução de ácidos sulfosalissílico a $3 \%$. Os extratos foram centrifugados por 900 s a uma velocidade de $3.360,70 \mathrm{~g}$.

\subsubsection{Determinação com reagente de ninidrina ácida}

Preparo do reagente:

Em um bequer foram adicionados $1,25 \mathrm{~g}$ de ninidrina, $30 \mathrm{~mL}$ de ácido acético glacial e $20 \mathrm{~mL}$ de ácido fosfórico $6 \mathrm{M}$, sob agitação, até a dissolução e homogeneização completa da solução.

Preparo da curva analítica de calibração de prolina:

As concentrações padrões de prolina usadas em triplicatas para a construção da curva de calibração foram: $0 ; 20 ; 40 ; 60 ; 80 ; 100 ; 120 ; 140 ; 160$; 180 e $200 \mathrm{mg}$ de prolina. $\mathrm{L}^{-1}$. De cada padrão, pipetou-se $2 \mathrm{~mL}$, em seguida foram adicionados $2 \mathrm{~mL}$ de ninidrina ácida e $2 \mathrm{~mL}$ de acético glacial. Os tubos foram tapados e mantidos em banho fervente por 1 hora sendo posteriormente resfriados em banho de gelo. Prosseguiu-se então à leitura a 520nm em espectrofotômetro obtendo-se a curva analítica de calibração e a equação da reta que melhor se enquadrou aos pontos obtidos. Procedeu-se então à leitura das amostras, e com a equação obtida mediante a curva de ajuste dos pontos, tornou- 
se possível a estimativa das concentrações de prolina (em $\mu \mathrm{g}$ de prolina. $\mathrm{g}^{-1}$ de material vegetal fresco) para cada tratamento proposto.

\subsubsection{Quantificação de Clorofila (modificado de Porra et al., 1989; Hendry \& Grime, 1993)}

\subsubsection{Extrações e quantificações}

Aproximadamente $100 \mathrm{mg}$ de material vegetal fresco foram pesados para esta análise em cada tratamento. Imediatamente após as pesagens foram colocados em gral de porcelana, no qual foi adicionado uma certa quantidade de nitrogênio líquido $\left(\mathrm{N}_{2}\right)$. A adição de $10 \mathrm{~mL}$ de cetona $80 \%(\mathrm{~V} / \mathrm{V})$ foi feita em seqüência. As amostras foram então centrifugadas por 100s a uma velocidade de $6.720,14 \mathrm{~g}$. Foi coletado somente o material em suspensão. As amostras purificadas de cada tratamento foram acondicionadas em recipiente escuro (evitando assim a degradação das clorofilas). A clorofila a foi lida a um comprimento de onda igual a $663 \mathrm{~nm}$ e a clorofila b a $646 \mathrm{~nm}$. A obtenção das equações de regressão para os cálculos de clorofila a $\left(12,25 . A^{663,6}-2,55 A^{646,6}\right)$, b $\left(20,31 . A^{646,6}-4,91 . A^{663,6}\right)$ e total $\left(17,76 . A^{646,6}-7,34 . A^{663,6}\right)$, podem ser obtidas no trabalho de Porra et al., 1989. Os valores de clorofila para os tratamentos são dados em $\mu \mathrm{g} \cdot \mathrm{mL}^{-1}$ da solução que posteriormente foram transformados e expressos em mg de clorofila. $\mathrm{mg}^{-1}$ de material vegetal fresco.

\subsubsection{Avaliação do potencial hídrico foliar}

A avaliação do potencial hídrico do tecido foliar também foi realizada psicrometricamente em câmeras modelo C-52 Wescor, acopladas a um microvoltímetro Wescor modelo HR-33T, nos diferentes períodos (aos $7^{\circ}$ e $21^{\circ}$ dias sob condições de deficiência hídrica e recuperação). 


\subsubsection{Avaliação anatômica dos tecidos foliares de E. grandis}

Para cada tratamento, foram coletadas as quatro (4) primeiras folhas da porção apical de cada grupo de brotações de E. grandis para cada um dos períodos analisados (aos 7 e 21 dias sob condições de deficiência hídrica e recuperação).

As amostras foram fixadas em solução de Karnovsky (Karnovsky, 1965) e levadas a uma bomba de vácuo para a retirada do ar contido nos tecidos. Posteriormente, as amostras foram desidratadas através da série alcoólicaetílica, infiltradas com a resina glicol metacrilato (Leica), secionadas transversalmente a $5 \mu \mathrm{m}$ de espessura, coradas com azul de toluidina 0,05\% em tampão fosfato e ácido cítrico Sakai, 1973) e montadas em resina sintética (Entellan).

As fotomicrografias dos materiais preparados em lâminas foram feitas em fotomicroscópio NIKON AFX-DX, com as escalas micrométricas fotografadas e ampliadas nas mesmas condições ópticas utilizadas.

\subsection{Análise dos dados}

Todos os dados foram submetidos inicialmente ao teste de análise de variância (Anova), visando a verificação de diferença significativa para $p<0,05$. Nos tratamentos em que essa diferença foi constatada, utilizou-se do teste de Tukey $(p<0,05)$ para comparação das médias.

Posteriormente, os dados foram analisados com a metodologia de componentes principais de análise multivariada. Nesta análise, a comparação entre os tratamentos foi realizada considerando-se todos os parâmetros avaliados conjuntamente. Para tanto, foi utilizado o programa PC-ORD versão 3.12 (MjM software, Oregon, USA, 1997). 


\section{RESULTADOS E DISCUSSÃO}

\subsection{Considerações gerais}

Através da observação visual, a princípio, ao longo dos 21 dias iniciais do experimento não foi possível observar nenhuma alteração externa por parte das brotações do clone de $E$. grandis. Por outro lado, verificou-se que à coloração do meio de cultura JADS apresentou um nítido escurecimento, em especial nos tratamentos $T_{4}$ e $T_{5}$, onde a suplementação de cálcio foi respectivamente 7,5 e $10 \mathrm{mmol}^{-1}$. Esses resultados também foram obtidos em ensaios preliminares com PEG a 10\%. Langer (2000) avaliando o crescimento de clones de E. urophylla $\times$ E. grandis cultivados em meio JADS também constatou escurecimento no meio de cultura em função da suplementação de cálcio na ordem de 7,5 e $10 \mathrm{mmol} . \mathrm{L}^{-1}$.

As alterações visuais tornaram-se evidentes a longo prazo, ou seja, após 21 dias do retorno do material às condições normais de crescimento. Assim como em testes preliminares (PEG a 10\%), a deficiência hídrica induzida por PEG $15 \%$ favoreceu a formação de tecido indiferenciado (calos) entre as brotações do clone de E. grandis no final do período de recuperação (Figura 2). Partindo do princípio que o estresse hídrico afeta o equilíbrio hormonal em especial de citocininas, ácido abscísico e etileno (Hale \& Orcutt, 1987; Larcher, 2000) é provável que a formação de calos observados tenham relação com um possível desbalanço hormonal. 

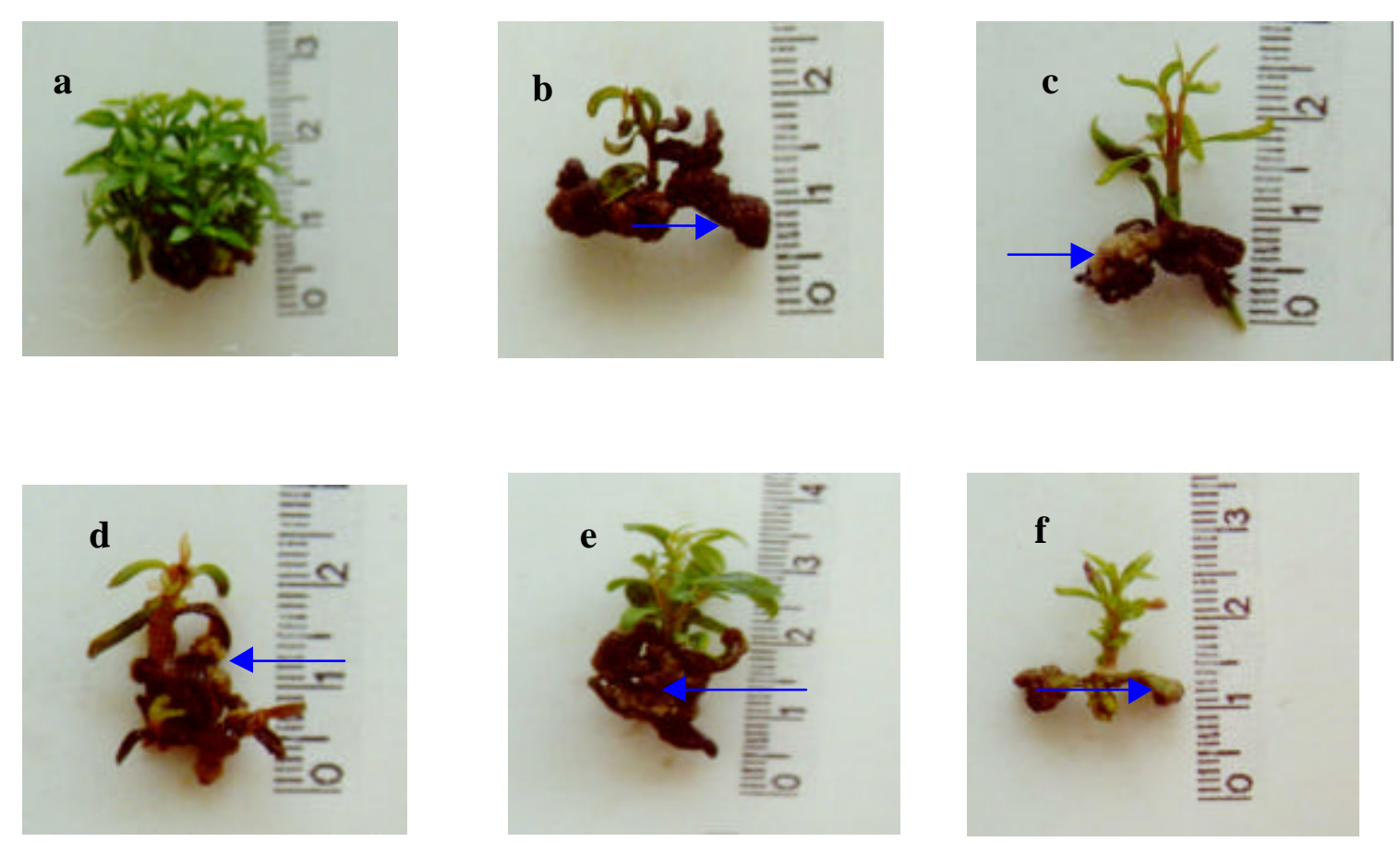

Figura 2 - Brotações de E. grandis 21 dias após o retorno às condições normais de crescimento (meio JADS) ("Recovery"). A Figura 2a corresponde ao tratamento controle $\left(\mathrm{C}_{\mathrm{T}}\right)$ e as Figuras $2 \mathrm{~b} ; \mathrm{c} ; \mathrm{d}$; e e f correspondem aos materiais que foram submetidos anteriormente ao cultivo sob condições de deficiência hídrica por PEG a 15\%: $2 b=T_{1}$ acréscimo de PEG 15\%; $2 \mathrm{c}=\mathrm{T}_{2}$ - acréscimo de PEG 15\% + 2,5 mmol. $L^{-1}$ de $\mathrm{Ca}^{2+} ; 2 \mathrm{~d}=\mathrm{T}_{3}$ - acréscimo de PEG $15 \%+5$ mmol. $\mathrm{L}^{-1}$ de $\mathrm{Ca}^{2+} ; 2 \mathrm{e}=\mathrm{T}_{4}$ - acréscimo de PEG $15 \%+7,5 \mathrm{mmol}^{-1} \mathrm{Le} \mathrm{Ca}^{2+}$ e $2 \mathrm{f}$ $=\mathrm{T}_{5}$ - acréscimo de PEG 15\%+10 mmol. $\mathrm{L}^{-1}$ de $\mathrm{Ca}^{2+}$ (Tabela 2). As setas indicam a formação de calos. 


\subsection{Avaliação da taxa de crescimento relativo (T.C.R)}

Não houve diferença significativa entre os tratamentos para a taxa de crescimento relativo (TCR) em brotações de E. grandis cultivadas sob estresse hídrico de $15 \%$.
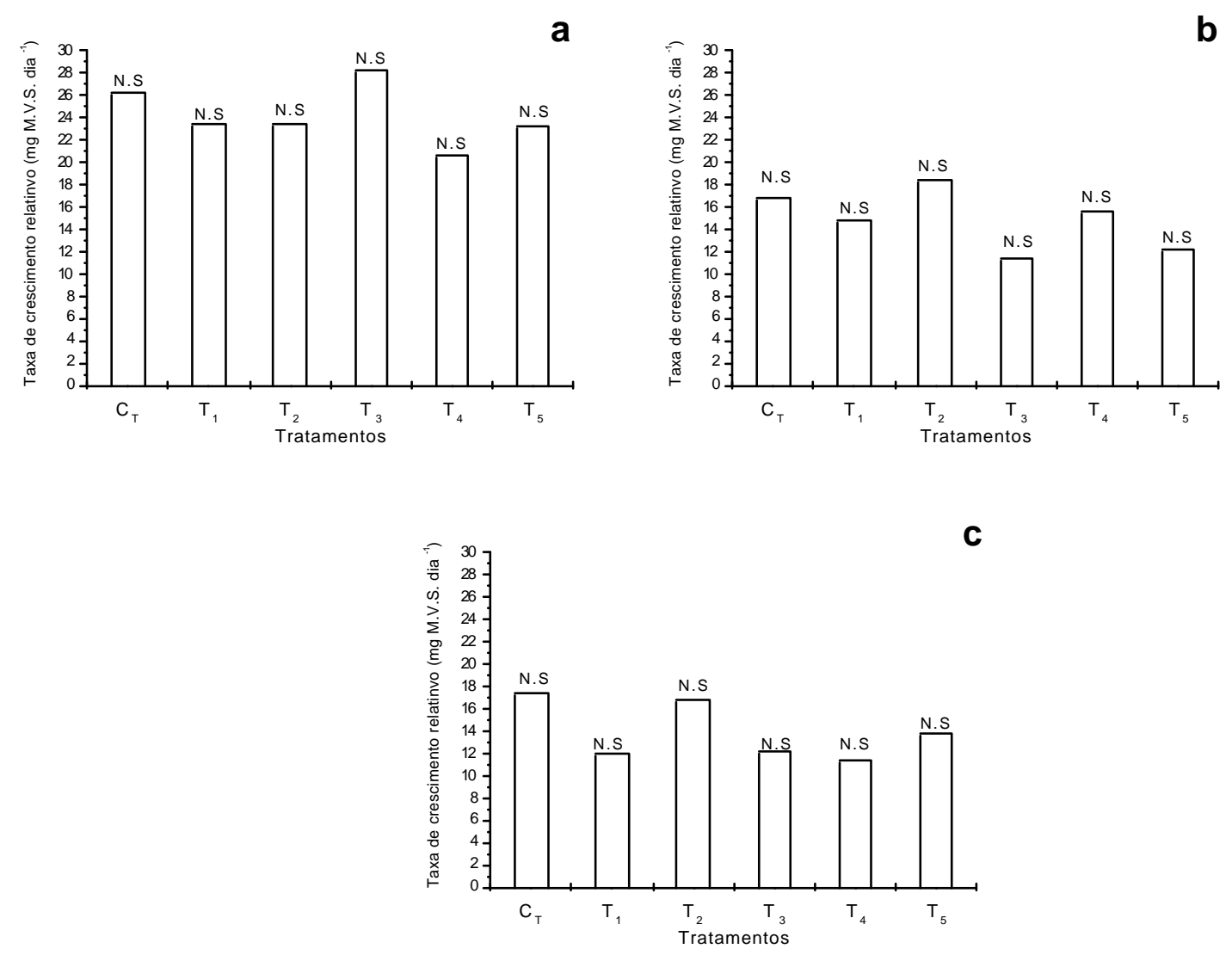

Figura 3 - Taxa de crescimento relativo de brotações de E. grandis cultivadas em meio JADS líquido $\left(\mathrm{C}_{\mathrm{T}}\right)$, com a adição de PEG 6000 a 15\% $\left(\mathrm{T}_{1}\right)$ e concentrações crescentes de cálcio: 5 a 15 mmol. $\mathrm{L}^{-1}\left(\mathrm{~T}_{2}, \mathrm{~T}_{3}, \mathrm{~T}_{4}\right.$ e $\mathrm{T}_{5}$ ) (Tabela 2). As quantificações e análises estatísticas foram realizadas para a comparação entre os tratamentos em cada período de amostragem. As Figuras $3 a$ e b correspondem aos períodos de estresse hídricos ao final de 7 e 21 dias, respectivamente, e a Figura 3c ao período de recuperação "recovery" após 21 dias de retorno do material às condições normais de crescimento (meio de cultura JADS). Barras com letras iguais para cada tratamento nos diferentes períodos não apresentam diferença pelo teste de Tukey ao nível de $5 \%$ de probabilidade. 
Esse resultado foi mantido constante a longo de todo o experimento. Isso somente comprovou que o nível de deficiência hídrica empregado não influenciou na taxa de crescimento relativo do material mesmo a longo prazo "recovery" (Figura 3a,b e c).

\subsection{Proteínas solúveis totais}

O teor de proteínas solúveis totais das brotações do clone de E. grandis que foram submetidas à deficiência hídrica induzida por PEG $15 \%$ por um período de 7 dias não apresentou diferença significativa entre os tratamentos (Figura 4a).

No entanto, aos 21 dias de submissão à deficiência hídrica, os valores foram significativamente maiores que o controle (Tukey $p<0,05$ ) em todos os tratamentos (Figura 4b). Não houve diferença estatística entre os tratamentos no período de recuperação (Figura 4c).

Borsani et al., (1999) estudando o conteúdo de proteínas solúveis totais da folhas de Lotus corniculatus sob deficiência hídrica verificaram que o conteúdo de proteínas não sofreu mudanças significativas.

Todavia, brotações de E. camaldulensis submetidas à deficiência hídrica apresentaram aumento na síntese de proteínas solúveis totais (Souza et al., 1999) como observado neste trabalho (Figura 4b). 


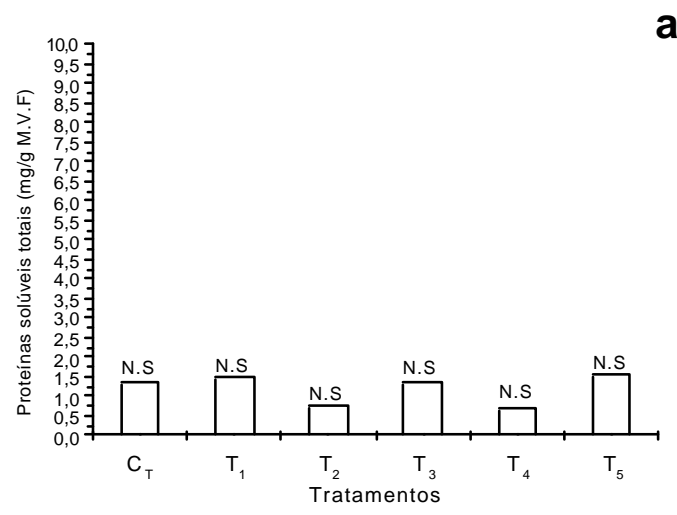

a
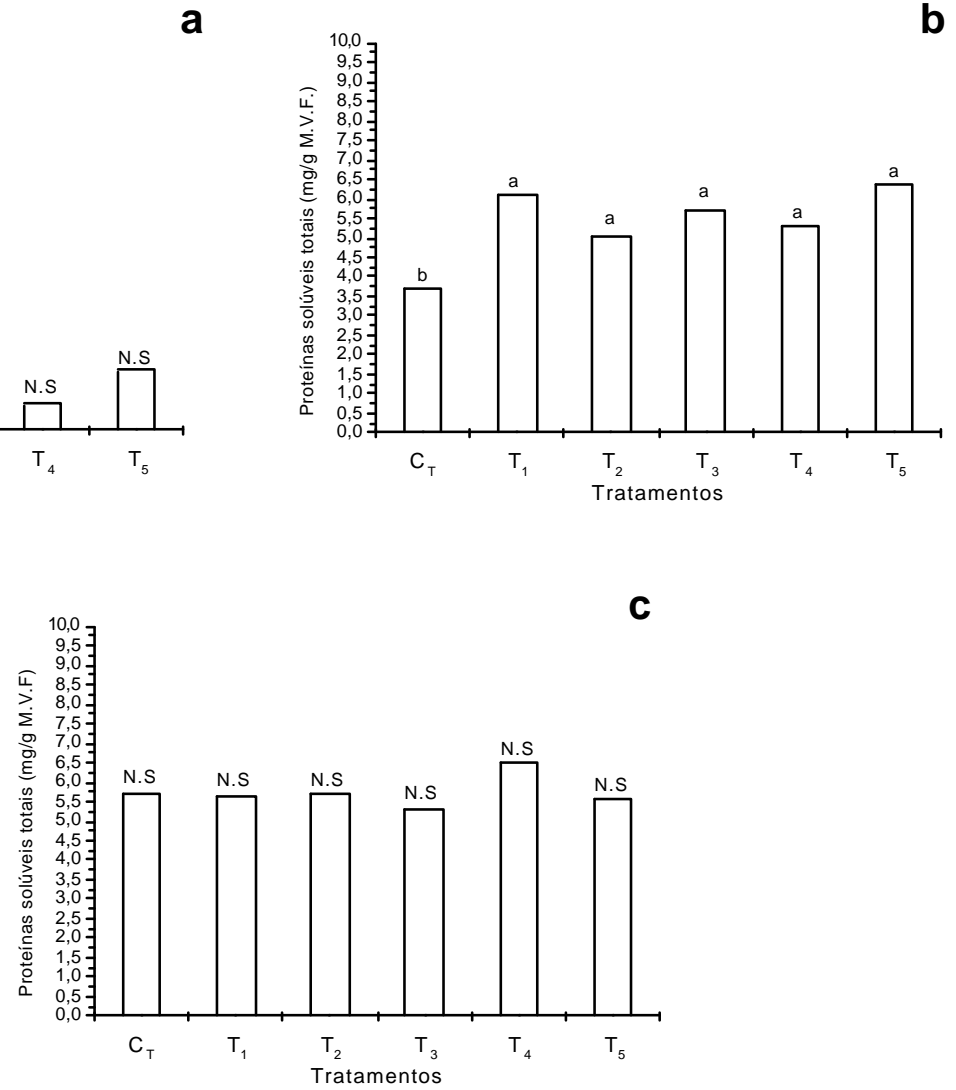

Figura 4 - Teores de proteínas solúveis totais em brotações de E. grandis cultivadas em meio JADS líquido $\left(\mathrm{C}_{\mathrm{T}}\right)$, com a adição de PEG 6000 a 15\% $\left(T_{1}\right)$ e concentrações crescentes de cálcio: 5 a $15 \mathrm{mmol}^{-L^{-1}}\left(T_{2}\right.$, $T_{3}, T_{4}$ e $T_{5}$ ) (Tabela 2). As quantificações e análises estatísticas foram realizadas para a comparação entre os tratamentos em cada período de amostragem. As Figuras 3a e b correspondem aos períodos de estresse hídricos ao final de 7 e 21 dias, respectivamente, e a Figura $3 \mathrm{c}$ ao período de recuperação "recovery" - após 21 dias de retorno do material às condições normais de crescimento (meio de cultura JADS). Barras com letras iguais para cada tratamento nos diferentes períodos não apresentam diferença pelo teste de Tukey ao nível de $5 \%$ de probabilidade. 


\subsection{Avaliação dos níveis de carboidratos não-estruturais solúveis totais}

A deficiência hídrica ao final da primeira semana favoreceu o acúmulo de carboidratos solúveis (Figura 5a). Nenhum dos tratamentos submetidos à deficiência hídrica induzida por PEG a 15\% conseguiu manter níveis de açúcares iguais ao controle ao final de uma semana de experimentação.

As concentrações de 2,5 $\left(\mathrm{T}_{2}\right)$ e 5 mmol. $\mathrm{L}^{-1}$ de $\mathrm{Ca}^{2+}$ suplementar $\left(\mathrm{T}_{3}\right)$ não apresentaram diferenças significativas em relação ao controle nos níveis de açúcares solúveis ao final de 21 dias de cultivo (Figura 5b). Isto sugere que 0 cálcio suplementar pode ter aumentado a tolerância das plantas a deficiência hídrica, permitindo que não houvessem alterações significativas nos níveis de açúcares solúveis, após 21 dias de cultivo iniciais (Figura 5a e b).

Ao final do período de recuperação (Figura $5 c$ ), as doses adicionais de cálcio não foram eficientes para manter os níveis de açúcares solúveis totais próximos aos do controle. O aumento observado nos níveis de açúcares sugere que a deficiência hídrica induziu efeitos tardios no material que já não se encontrava com doses suplementares de cálcio. Isso corrobora com a hipótese do cálcio como um agente estabilizador. 

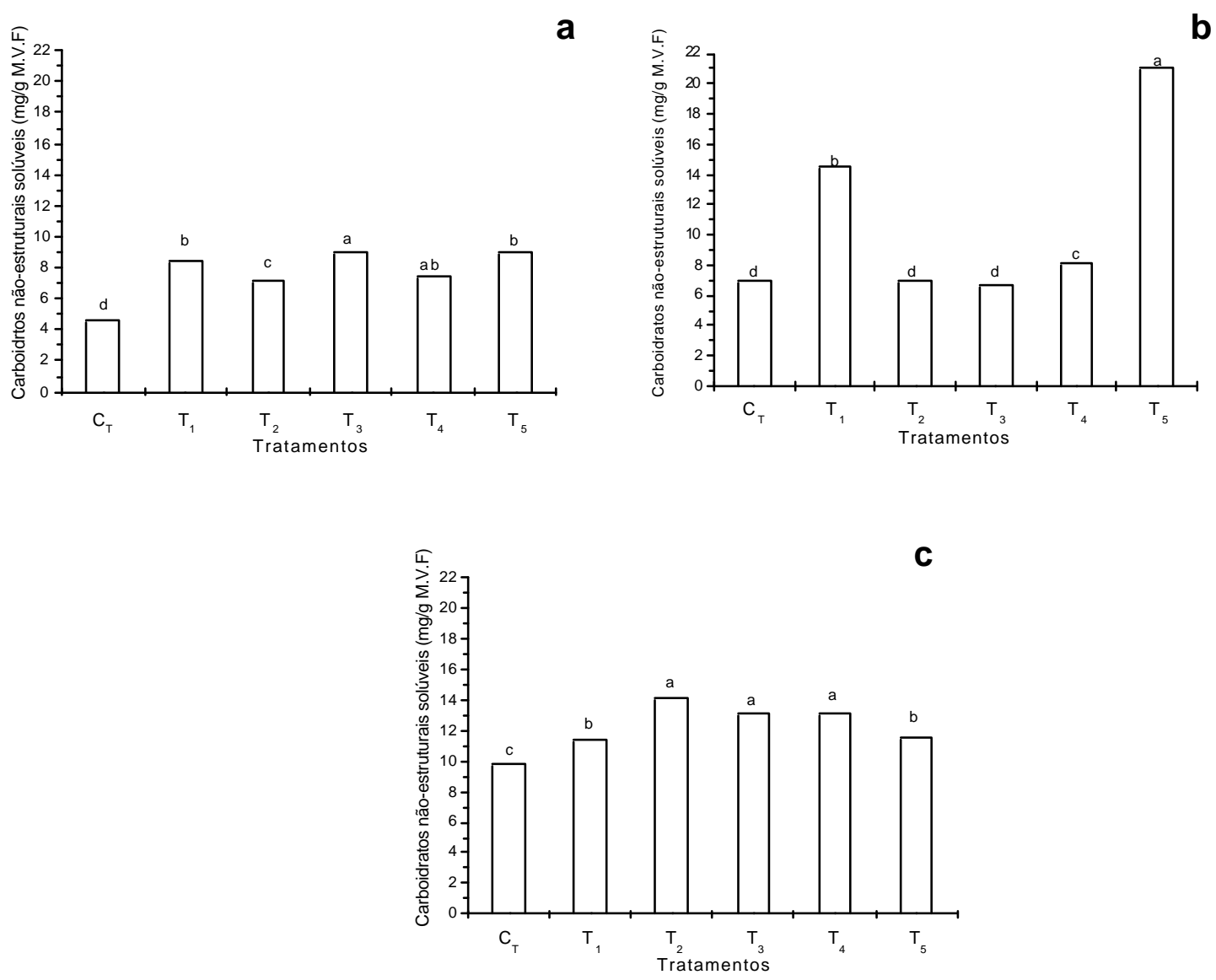

Figura 5 - Teores de carboidratos não-estruturais solúveis em brotações de E. grandis cultivadas em meio JADS líquido $\left(\mathrm{C}_{\mathrm{T}}\right)$, com a adição de PEG 6000 a 15\% $\left(T_{1}\right)$ e concentrações crescentes de cálcio: 5 a 15 mmol.L $L^{-1}\left(T_{2}, T_{3}, T_{4}\right.$ e $\left.T_{5}\right)$ (Tabela 2). As quantificações e análises estatísticas foram realizadas para a comparação entre os tratamentos em cada período de amostragem. As Figuras $3 a$ e b correspondem aos períodos de estresse hídricos ao final de 7 e 21 dias, respectivamente, e a Figura 3c ao período de recuperação "recovery" - após 21 dias de retorno do material às condições normais de crescimento (meio de cultura JADS). Barras com letras iguais para cada tratamento nos diferentes períodos não apresentam diferença pelo teste de Tukey ao nível de $5 \%$ de probabilidade. 


\subsection{Avaliação dos níveis de aminoácidos solúveis totais}

Após 7 dias de cultivo sob deficiência hídrica induzida com $15 \%$ de PEG, os teores de aminoácidos solúveis totais nos tecidos de E. grandis demonstraram que a suplementação de 5 (tratamento $\mathrm{T}_{3}$ ) a $10 \mathrm{mmol}^{-\mathrm{L}^{-1}}$ de $\mathrm{Ca}^{2+}$ (tratamento $T_{5}$ ) foram suficientes para a manutenção dos níveis desses solutos osmóticos compatíveis próximos aos níveis do controle (Figura 6a). No entanto, ao final do período (21 dias) nenhuma das doses utilizadas surtiu efeito no sentido de manter os níveis desses aminoácidos em relação ao controle (Figura 6b). Estes resultados sugerem que as doses de cálcio suplementares $\left(\begin{array}{llll}T_{3} & \text { a } & T_{5}\end{array}\right)$ foram suficientes para aumentar a tolerância (estabilidade) das plantas à deficiência hídrica, sem aumentar significativamente os níveis de aminoácidos solúveis, apenas por um curto período de cultivo (Figura 6a). Todavia, é provável que em função do esgotamento natural dos meios ao longo do cultivo, reduzindo os níveis de cálcio disponível e de outros nutrientes, tenha ocorrido uma redução na tolerância por parte dos tecidos das brotações de E. grandis que passaram a responder à deficiência hídrica acumulando osmólitos como forma de redução do potencial hídrico interno (Figura 6b).

No final do período de recuperação com exceção do tratamento com cálcio suplementar $\mathrm{T}_{4}\left(7,5 \mathrm{mmol} \cdot \mathrm{L}^{-1}\right.$ de $\left.\mathrm{Ca}^{2+}\right)$, todos os demais tratamentos com cálcio suplementar $\left(T_{2} ; T_{3}\right.$ e $\left.T_{5}\right)$, diminuíram os níveis de aminoácidos solúveis, deixando-os estatisticamente iguais ao controle (Figura 6c).

Provavelmente, o aumento na síntese de aminoácidos durante o período de estresse (21 dias) teve influência direta no período de recuperação, como um componente de ajuste osmótico (Larcher, 2000). Todavia, a recuperação do material ocorreu apenas nos tratamentos com $\mathrm{Ca}^{2+}$ suplementar evidenciando o efeito deste elemento no processo de resposta ao estresse hiper-osmótico como um mensageiro secundário (Malhó et al., 1998). 

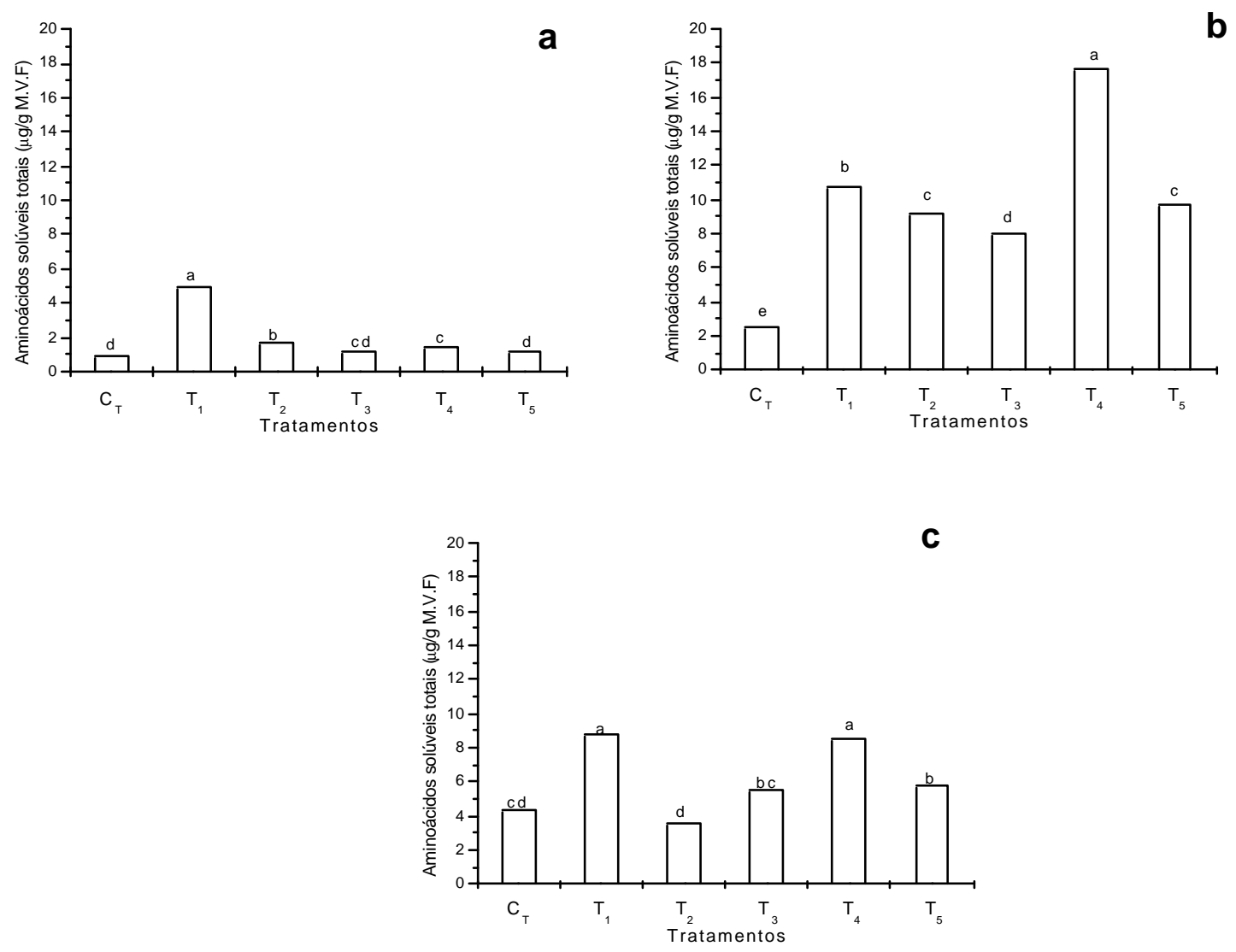

Figura 6 - Teores de aminoácidos solúveis totais em brotações de E. grandis cultivadas em meio JADS líquido $\left(\mathrm{C}_{\mathrm{T}}\right)$, com a adição de PEG 6000 a 15\% $\left(T_{1}\right)$ e concentrações crescentes de cálcio: 5 a 15 mmol. $\mathrm{L}^{-1}\left(T_{2}\right.$, $T_{3}, T_{4}$ e $T_{5}$ ) (Tabela 2). As quantificações e análises estatísticas foram realizadas para a comparação entre os tratamentos em cada período de amostragem. As Figuras $3 a$ e b correspondem aos períodos de estresse hídricos ao final de 7 e 21 dias, respectivamente, e a Figura $3 c$ ao período de recuperação "recovery" - após 21 dias de retorno do material às condições normais de crescimento (meio de cultura JADS). Barras com letras iguais para cada tratamento nos diferentes períodos não apresentam diferença pelo teste de Tukey ao nível de $5 \%$ de probabilidade. 


\subsection{Avaliação dos teores de prolina}

O estresse hídrico a $15 \%$ de PEG favoreceu o aumento na concentração de prolina nos tecidos de E. grandis, em especial nos tratamentos sem doses de cálcio suplementar $\left(T_{1}\right)$ e com doses de 7,5 e 10 mmol.L-1 ( $T_{4}$ e $\left.T_{5}\right)$ (Figuras $7 \mathrm{a}$ e b). Esses efeitos foram amenizados pelas doses de cálcio suplementadas ao meio de cultura, em especial no tratamento $T_{2}\left(2,5 \mathrm{mmol}^{-1} \mathrm{~L}^{-1}\right.$ de $\mathrm{Ca}^{2+}$ ) (Figura 7a,b e c).

O retorno do material submetido às condições normais de crescimento ("recovery") revelou que o período de submissão do material ao estresse influenciou no aumento da síntese de prolina em todos os materiais, em especial no tratamento onde foi acrescentado $10 \mathrm{mmol}^{-\mathrm{L}^{-1}}$ de $\mathrm{Ca}^{2+}$ ao meio de cultura $\left(\mathrm{T}_{5}\right)$ (Figura 7c). A alta concentração de prolina encontrada nesse tratamento $\left(T_{5}\right)$ pode ser decorrente da toxidez causada pelos ânios $\mathrm{Cl}^{-}$liberados em função da dose e fonte de cálcio suplementada $\left(\mathrm{CaCl}_{2}\right)$ ao meio de cultura JADS.

Prolina e carboidratos são os dois mais importantes solutos orgânicos acumulados em plantas superiores sob condições de estresse hídrico ou salino. Embora nenhuma relação causal tenha sido estabelecida entre o acúmulo desses dois metabólitos, acredita-se que os carboidratos não-estruturais atuem diretamente em enzimas envolvidas no metabolismo da prolina (Laher et al., 1993). Ao compararmos os níveis de prolina (figura $7 b$ ) com os níveis de carboidratos apresentados em nossos experimentos, em especial aos 21 dias sob estresse (Figura $5 b$ ) notamos que estes possivelmente serviram como fonte de $\mathrm{C}$ e $\mathrm{H}$ para o suprimento e metabolismo de prolina via glutamato (Stewart, 1978). 

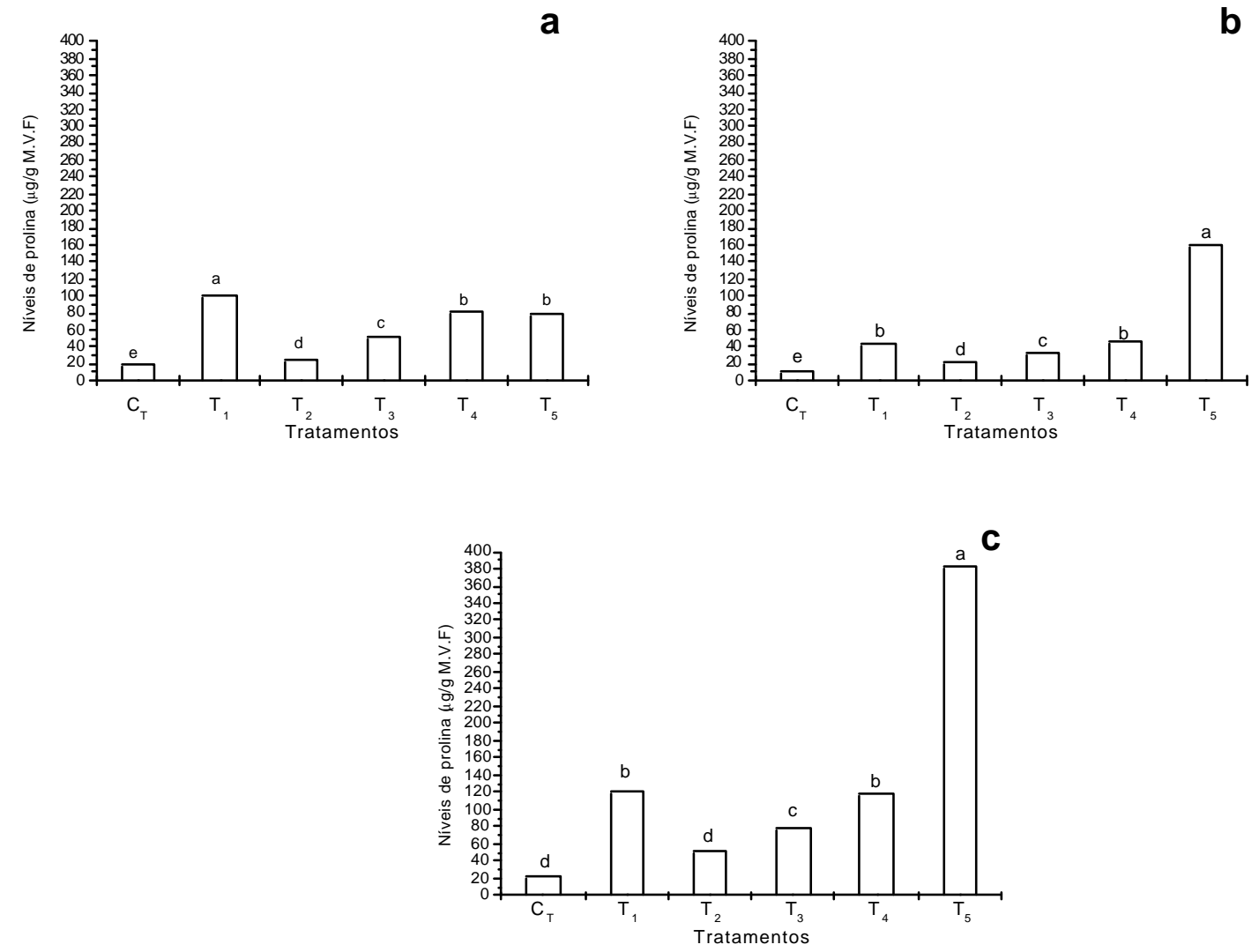

Figura 7 - Teores de prolina em brotações de E. grandis cultivadas em meio JADS líquido $\left(\mathrm{C}_{\mathrm{T}}\right)$, com a adição de PEG 6000 a 15\% $\left(\mathrm{T}_{1}\right)$ e concentrações crescentes de cálcio: 5 a $15 \mathrm{mmol}^{-1} \mathrm{~L}^{-1}\left(T_{2}, T_{3}, T_{4}\right.$ e $\left.T_{5}\right)$ (Tabela 2). As quantificações e análises estatísticas foram realizadas para a comparação entre os tratamentos em cada período de amostragem. As Figuras $3 a$ e b correspondem aos períodos de estresse hídricos ao final de 7 e 21 dias, respectivamente, e a Figura $3 c$ ao período de recuperação "recovery" - após 21 dias de retorno do material às condições normais de crescimento (meio de cultura JADS). Barras com letras iguais para cada tratamento nos diferentes períodos não apresentam diferença pelo teste de Tukey ao nível de $5 \%$ de probabilidade. 


\subsection{Avaliação dos teores de clorofila}

\subsubsection{Avaliação dos teores de clorofila a}

Não existe tendência estabelecida ao final da primeira semana de experimentação com estresse hídrico induzido por PEG a 15\% para os teores de clorofila a. Praticamente, todos os tratamentos ao final dos 21 dias atingiram níveis de clorofila a próximos ao controle (CT) - (Figura 8a).

Embora, os efeitos da deficiência hídrica não tenham sido detectados no período de submissão do material à deficiência hídrica (Figuras $8 \mathrm{a}$ e b), seu efeito tornou-se pronunciado em longo prazo, ou seja, no final do período de recuperação do material (figura $8 \mathrm{c}$ ). $\mathrm{O}$ único tratamento no qual a expressão de clorofila a foi próxima ao controle em valores absolutos no final da recuperação foi o tratamento $\mathrm{T}_{2}$, onde o nível de $\mathrm{Ca}^{2+}$ suplementado foi de $2,5 \mathrm{mmol} . \mathrm{L}^{-1}$. A síntese de clorofila nos demais tratamentos parece ter sido alterada (Figura 8c). 

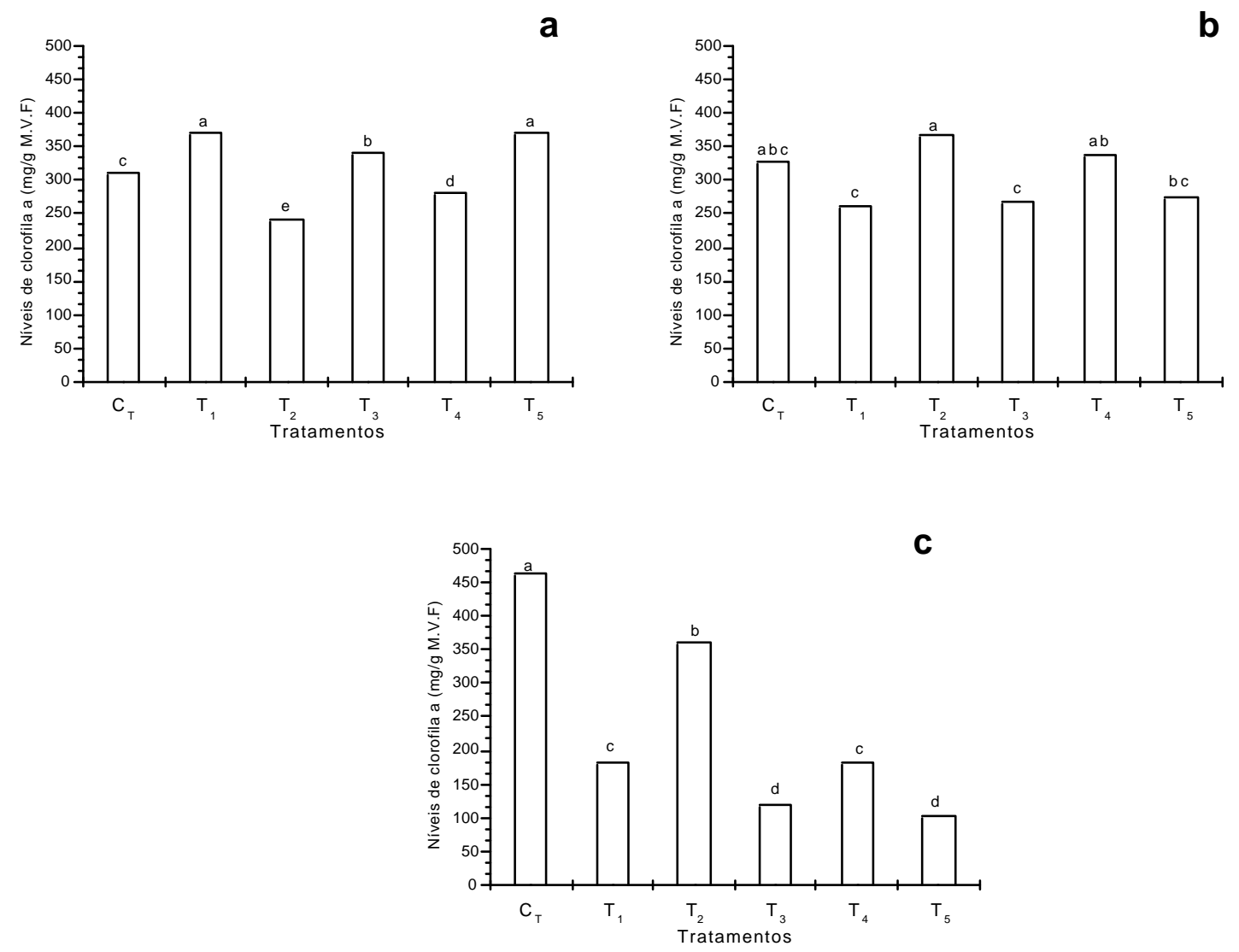

Figura 8 - Teores de clorofila a em brotações de E. grandis cultivadas em meio JADS líquido $\left(\mathrm{C}_{\mathrm{T}}\right)$, com a adição de PEG 6000 a $15 \%\left(\mathrm{~T}_{1}\right)$ e concentrações crescentes de cálcio: 5 a $15 \mathrm{mmol}^{-1} \mathrm{~L}^{-1}\left(T_{2}, T_{3}, T_{4}\right.$ e $\left.T_{5}\right)$ (Tabela 2). As quantificações e análises estatísticas foram realizadas para a comparação entre os tratamentos em cada período de amostragem. As Figuras $3 a$ e $b$ correspondem aos períodos de estresse hídricos ao final de 7 e 21 dias, respectivamente, e a Figura $3 c$ ao período de recuperação "recovery" - após 21 dias de retorno do material às condições normais de crescimento (meio de cultura JADS). Barras com letras iguais para cada tratamento nos diferentes períodos não apresentam diferença pelo teste de Tukey ao nível de 5\% de probabilidade. 


\subsubsection{Avaliação dos teores de clorofila b}

O estresse hídrico favoreceu a concentração de clorofila b na primeira semana sob condições de deficiência hídrica induzida por PEG a 15\%. As doses de cálcio suplementadas ao meio JADS de 5 a 10 mmol. $L^{-1}\left(T_{3}, T_{4}\right.$ e $\left.T_{5}\right)$ amenizaram esse efeito, favorecendo a similaridade estatística desses tratamentos com o controle (Figura 9a).

Ao final do período de estresse, não houve diferença significativa para Tukey ao nível de $5 \%$ de probabilidade entre os tratamentos (Figura 9b).

Houve recuperação do material quanto ao nível de clorofila b. Nota-se que dos materiais submetidos à deficiência hídrica o único a apresentar-se com igualdade estatística com o controle foi o tratamento $\mathrm{T}_{2}$ (onde foi adicionado 2,5 mmol.L ${ }^{-1}$ de $\mathrm{Ca}^{2+}$ ) - (Figura 9c). 

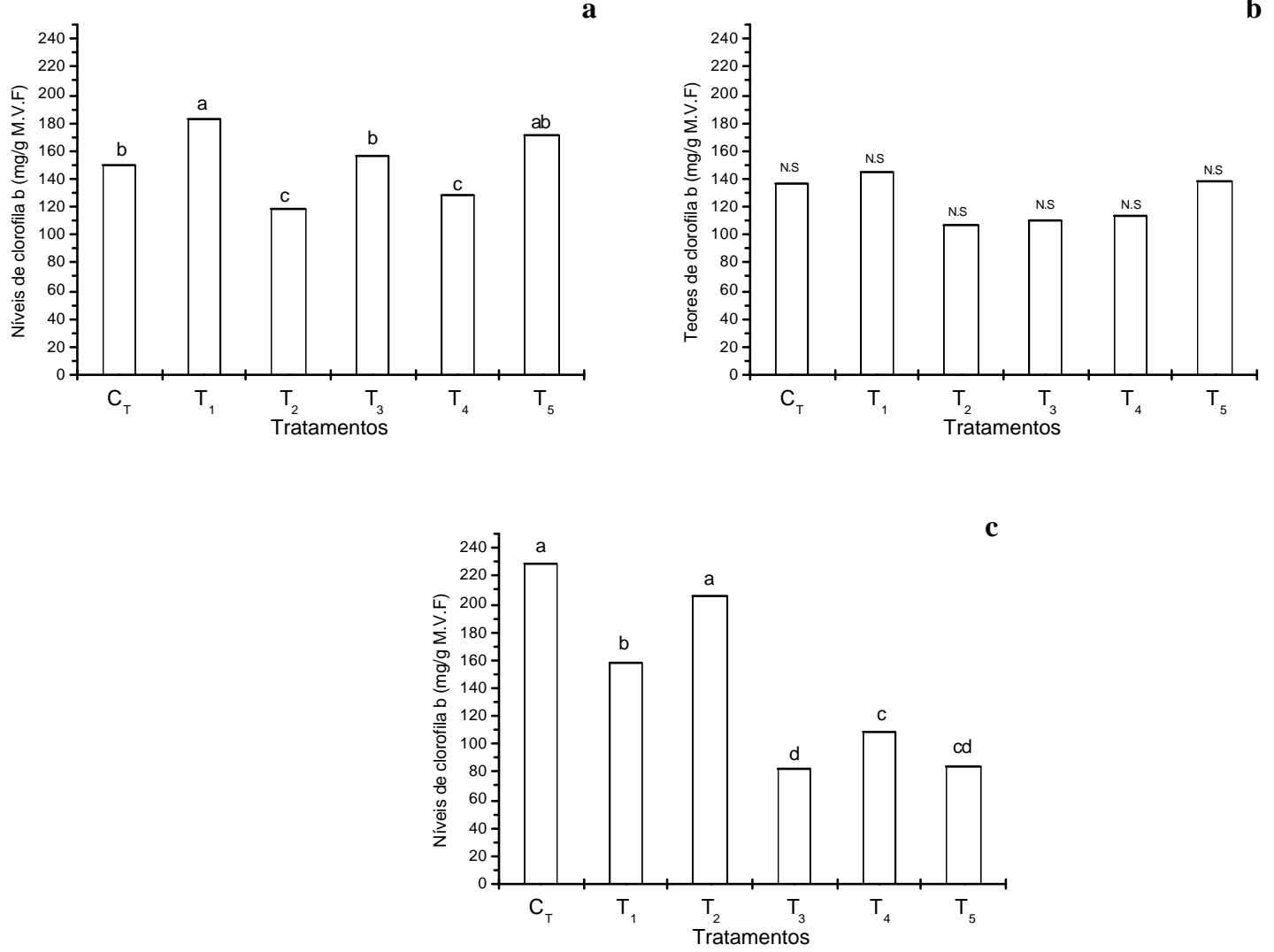

Figura 9 - Teores de clorofila b em brotações de E. grandis cultivadas em meio JADS líquido $\left(\mathrm{C}_{\mathrm{T}}\right)$, com a adição de PEG 6000 a $15 \%\left(\mathrm{~T}_{1}\right)$ e concentrações crescentes de cálcio: 5 a $15 \mathrm{mmol}^{-1} \mathrm{~L}^{-1}\left(T_{2}, T_{3}, T_{4}\right.$ e $\left.T_{5}\right)$ (Tabela 2). As quantificações e análises estatísticas foram realizadas para a comparação entre os tratamentos em cada período de amostragem. As Figuras $3 a$ e b correspondem aos períodos de estresse hídricos ao final de 7 e 21 dias, respectivamente, e a Figura $3 c$ ao período de recuperação "recovery" - após 21 dias de retorno do material às condições normais de crescimento (meio de cultura JADS). Barras com letras iguais para cada tratamento nos diferentes períodos não apresentam diferença pelo teste de Tukey ao nível de $5 \%$ de probabilidade. 


\subsubsection{Avaliação dos teores de clorofila total}

A deficiência hídrica parece ter favorecido um aumento na síntese de clorofila total ao final da primeira semana sob condições de estresse hídrico por $15 \%$ de PEG. No entanto, para o tratamento $\mathrm{T}_{3}$, suplementado com $5 \mathrm{mmol}^{-1} \mathrm{~L}^{-1}$ de $\mathrm{Ca}^{2+}$ esse efeito não foi pronunciado, uma vez que se apresentou estatisticamente igual ao controle (Figura 10a).

Já aos 21 dias de experimentação, a deficiência hídrica pode ter contribuído para a redução do nível de clorofila total. Apenas os tratamentos com doses de cálcio total igual a 2,5 (tratamento $T_{2}$ ) e 7,5 mmol. $\mathrm{L}^{-1}\left(\mathrm{~T}_{4}\right)$ alcançaram valores estatisticamente iguais ao controle. (Figura 10b).

Após o período de recuperação do material, todos os tratamentos diferiram estatisticamente do controle, apresentando níveis mais baixos de clorofila total. Essa diminuição na concentração total de clorofila decorrente do estresse hídrico pode ter ocorrido em função da desintegração de membranas, devido ao estresse oxidativo e comum em espécies menos tolerantes à seca (Mornan et al, 1994). Durante todo o período de recuperação, a dose de 2,5

mmol. $\mathrm{L}^{-1}$ de $\mathrm{Ca}^{2+}$ suplementar $\left(\mathrm{T}_{2}\right)$ foi a que apresentou um melhor desempenho quando comparado ao controle, sugerindo que não só a deficiência hídrica como também as doses de cálcio induziram à alteração na síntese de clorofila total em longo prazo (Figura 10c). 
a

b
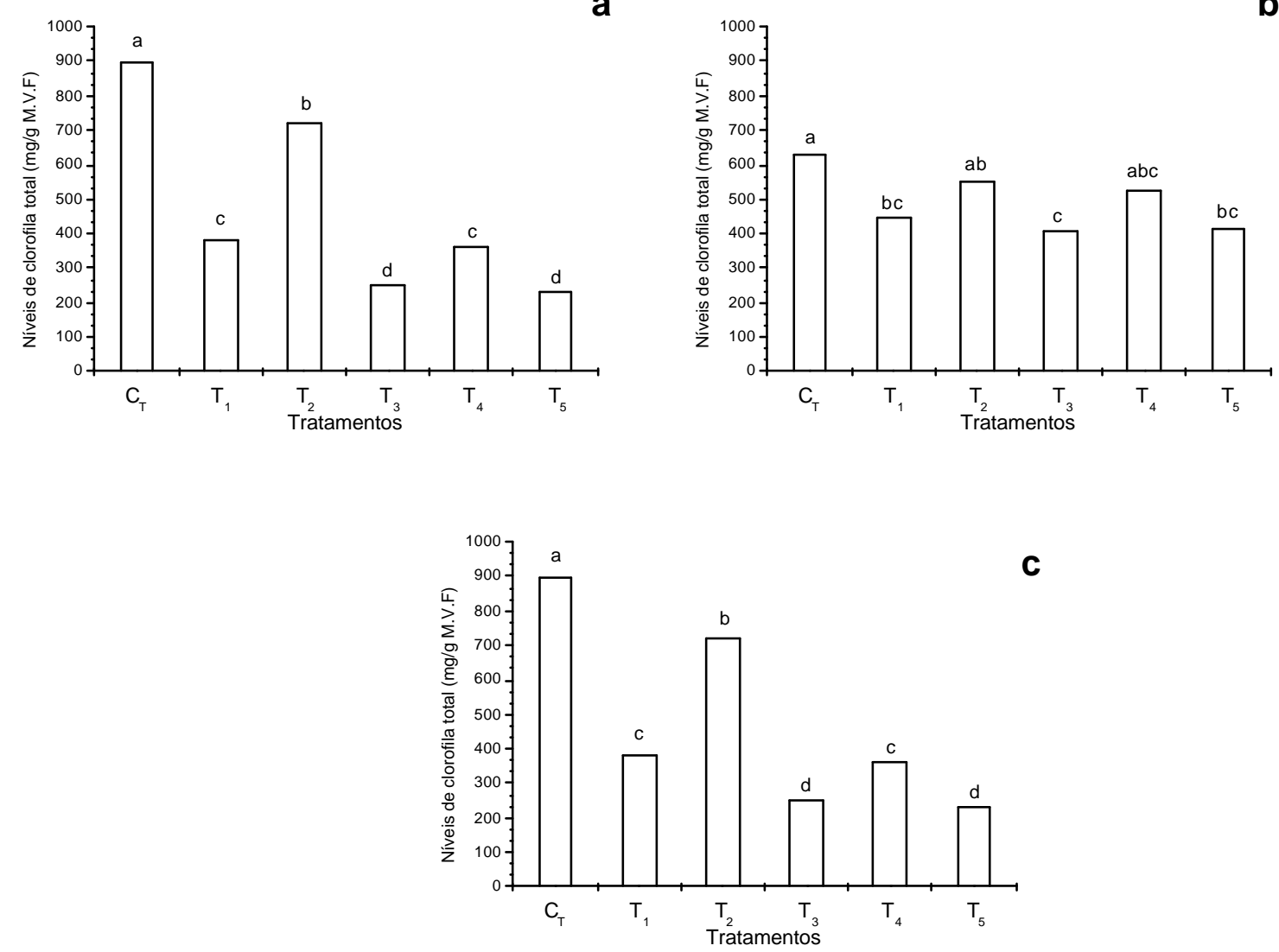

Figura 10 - Teores totais de clorofila em brotações de E. grandis cultivadas em meio JADS líquido $\left(\mathrm{C}_{\mathrm{T}}\right)$, com a adição de PEG 6000 a 15\% ( $\left.\mathrm{T}_{1}\right)$ e concentrações crescentes de cálcio: 5 a 15 mmol. $\mathrm{L}^{-1}\left(\mathrm{~T}_{2}, \mathrm{~T}_{3}, \mathrm{~T}_{4}\right.$ e $\left.\mathrm{T}_{5}\right)$ (Tabela 2). As quantificações e análises estatísticas foram realizadas para a comparação entre os tratamentos em cada período de amostragem. As Figuras $3 a$ e b correspondem aos períodos de estresse hídricos ao final de 7 e 21 dias, respectivamente, e a Figura 3c ao período de recuperação "recovery" - após 21 dias de retorno do material às condições normais de crescimento (meio de cultura JADS). Barras com letras iguais para cada tratamento nos diferentes períodos não apresentam diferença pelo teste de Tukey ao nível de 5\% de probabilidade. 


\subsection{Avaliação do potencial hídrico foliar}

O potencial hídrico foliar reflete as condições da dinâmica do processo de transporte no sistema solo-planta-atmosfera, constituindo o principal componente responsável pelo fluxo de água na planta (Ferreira et al., 1993).

Os resultados apresentados para $\circ\left(\psi_{t}\right)$ estiveram dentro da faixa de estudo de outros trabalhos. Lima (1995), trabalhando com mudas de espécies de Eucalyptus spp. sob estresse hídrico, encontrou valores com variações entre -0,30 a - 2,1 MPa. De acordo com Reis (1986), um potencial hídrico na ordem de -3,9 MPa pode ocasionar danos irreversíveis à folhas de E. camaldulensis Dehn.

Ao longo de todo o experimento, ocorreram as seguintes variações para o potencial hídrico foliar submetido à deficiência hídrica induzida por PEG a 15\% : $-0,4 \mathrm{MPa}$ ( $T_{2}$, final do período de estresse) a $-2,4$ ( $T_{5}$ - final período de estresse) estando de acordo com os obtidos por Lima (1995). As demais variações podem ser visualizadas no gráfico (Figura 11), sendo que de uma maneira geral houve um nítido aumento do potencial hídrico dos tecidos após o período de recuperação (Figura 11). 


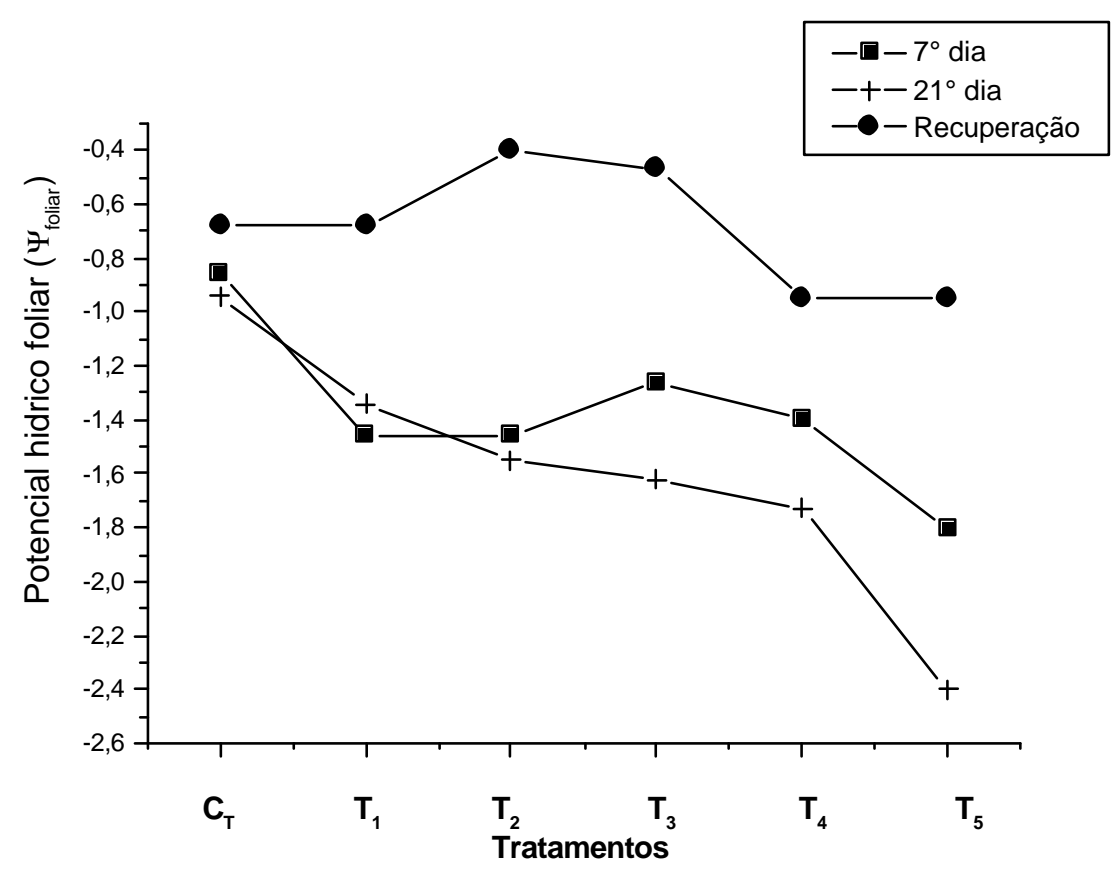

Figura 11 - Potenciais hídricos foliares do clone de E. grandis ao longo de três períodos de análise: 7 ( ) e 21 (+) dias sob condições de restrição hídrica induzida por PEG 15\% e recuperação $(\bullet)(21$ dias após as condições normais de crescimento no meio de cultura JADS.

De acordo com os parâmetros analisados acredita-se que açúcares solúveis assim como, prolina e aminoácidos solúveis contribuíram de maneira direta para a diminuição do potencial osmótico dos tecidos foliares de brotações de E. grandis em função do balanço hídrico negativo induzido pela suplementação de PEG $15 \%$ no meio de cultura, através do processo conhecido como osmoregulação (Munns, 1988; Larcher, 2000). 


\subsection{Avaliação dos parâmetros relacionados à anatomia foliar}

A submissão do material à deficiência hídrica $(-0,9 \mathrm{MPa}$; ) parece não ter influenciado na diferenciação dos tecidos foliares. No entanto, dados da literatura apontam que a deficiência hídrica $(-3,0 \mathrm{MPa})$ pode induzir a alterações na estrutura anatômica de folhas de Eucalyptus: colapso das células, atraso na diferenciação dos tecidos, desorganização do feixe vascular e da epiderme e alterações na espessura do mesofilo e da epiderme (Souza et al., 1999).

Comparando as porções medianas e laterais das folhas submetidas ao déficit hídrico induzido de $-0,9 \mathrm{MPa}$ ( $\mathrm{T}_{1}$, sem cálcio suplementar) com as controle (folhas crescidas em meio de cultura JADS, sem o uso do agente estressor PEG $15 \%$ e sem cálcio suplementar; -0,16MPa) verificamos um grande acúmulo de compostos de natureza não identificada em todos os tecidos foliares. Embora não tenha sido feito nenhum teste histoquímico, é possível que a natureza desses compostos possa ser de origem fenólica (Figuras 12 e 13 B). 

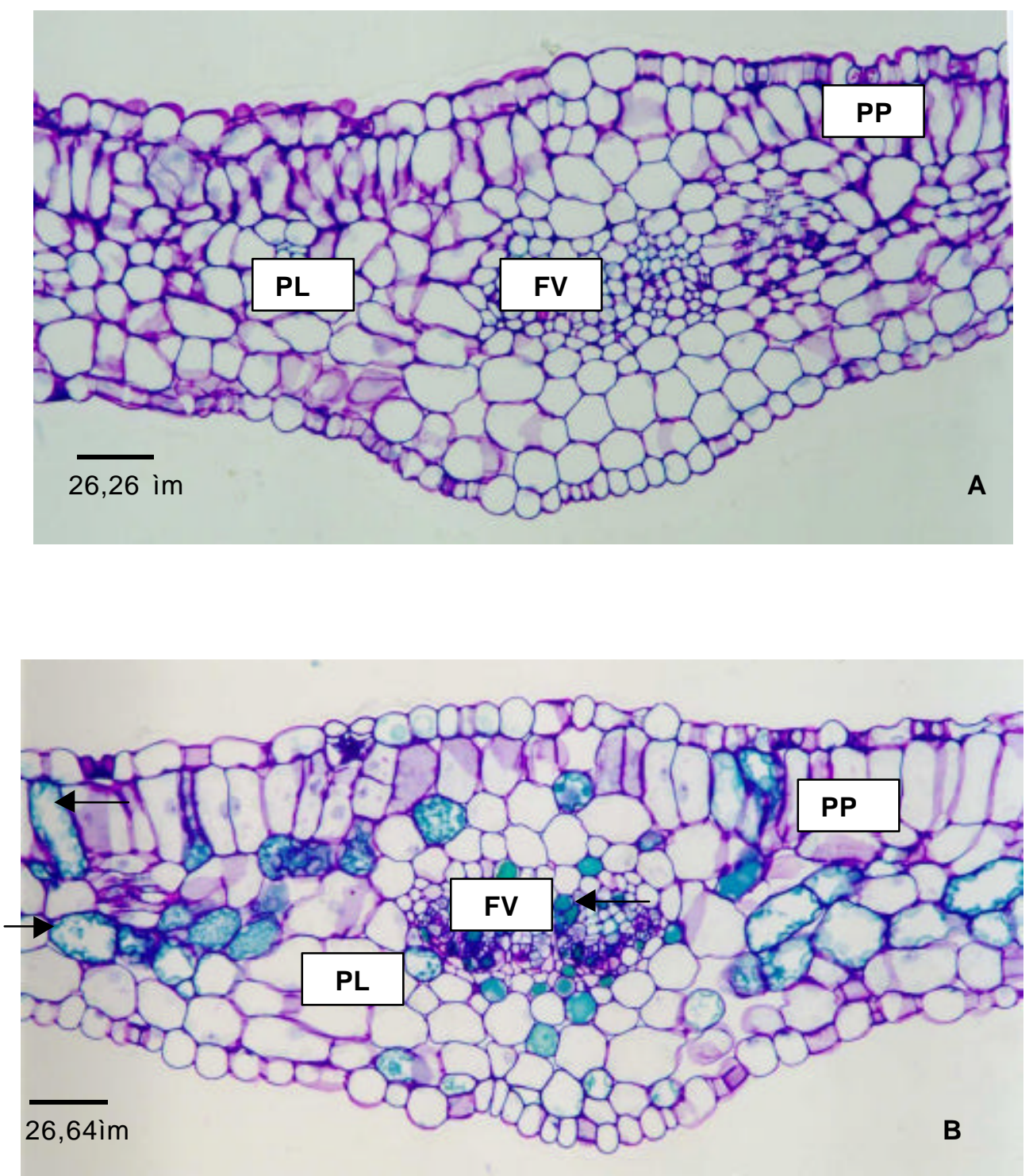

Figura 12 - Micrografias de secções transversais da porção média de limbo foliar de E. grandis sob condições normais (Controle, - $0,16 \mathrm{MPa}$ ) de cultivo em meio de cultura JADS (A) e sob condições de deficiência hídrica induzida por PEG 15\% ( $\left.\mathrm{T}_{1}=-0,9 \mathrm{MPa}\right)$ aos 21 dias $(B)$. ( $P P=$ Parênquima paliçádico; $P L=$ parênquima lacunoso; $\mathrm{FV}=$ sistema vascular). As setas acusam possível acúmulo de compostos fenólicos. 

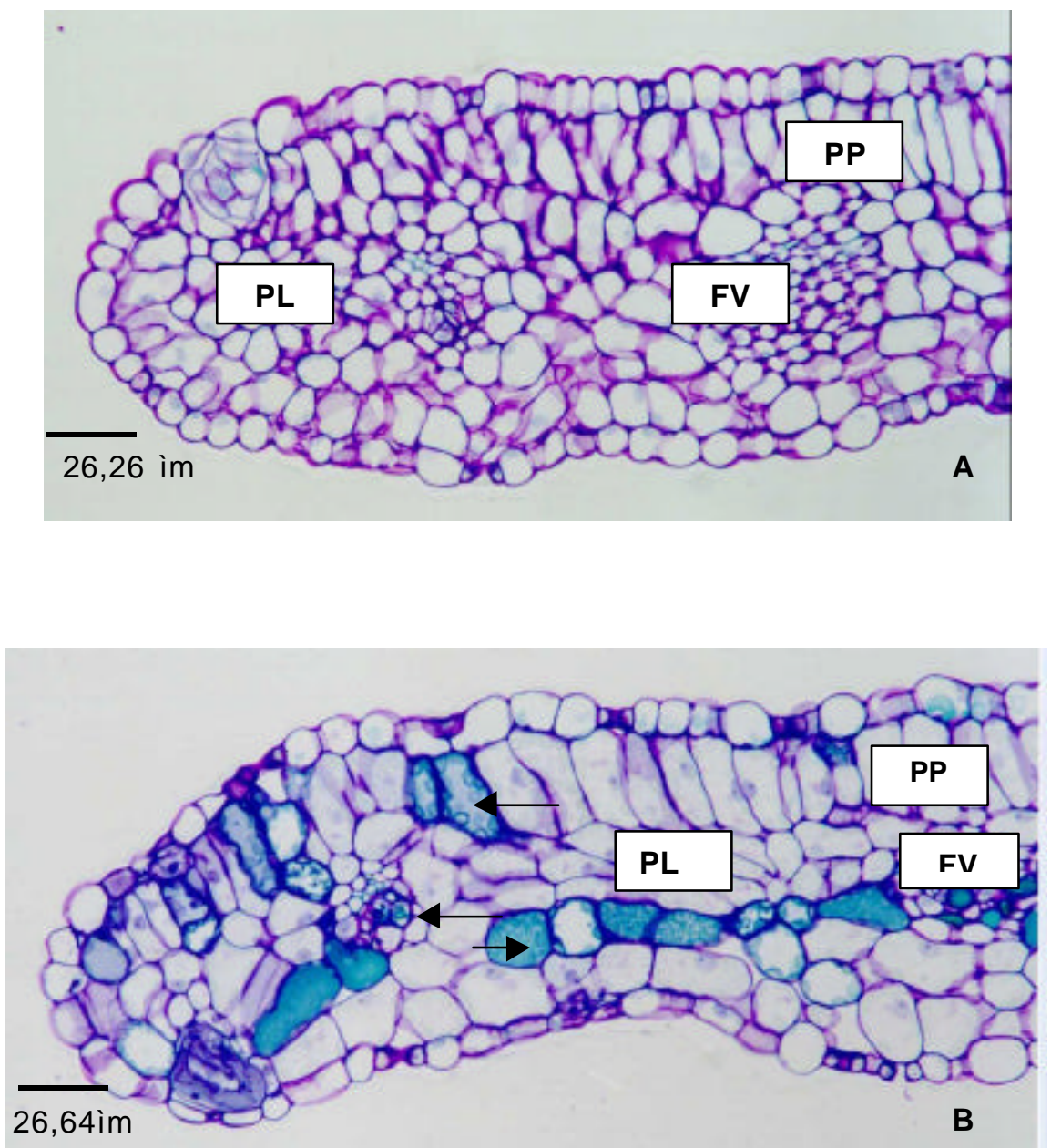

Figura 13 - Micrografias de secções transversais da porção lateral do limbo foliar de E. grandis sob condições normais (Controle, -0,16 MPa) de cultivo em meio de cultura JADS (A) e sob condições de deficiência hídrica induzida por PEG 15\% ( $\left.\mathrm{T}_{1}=-0,9 \mathrm{MPa}\right)$ aos 21 dias (B). ( $\mathrm{PP}=$ Parênquima paliçádico; $\mathrm{PL}=$ parênquima lacunoso; $\mathrm{FV}$ = feixe vascular). As setas acusam possível acúmulo de compostos fenólicos. 


\subsection{Análise de componentes principais}

A ordenação dos tratamentos ao longo dos eixos no primeiro período de amostragem e análise de brotações de E. grandis (7 dias sob condições de deficit hídrico de 15\%) demonstrou que o eixo 1 explicou 52,89\% dos dados. Para o componente principal 2 (eixo 2) essa explicação foi baixa, $21,35 \%$. No total, os dois eixos conseguiram explicar $74,24 \%$ da distribuição geral dos dados (Figura 14).

Essa correlação de dados demonstrou que para a primeira semana sob deficiência hídrica de PEG $15 \%$, as quatro primeiras variáveis a contribuírem para esse padrão de distribuição de acordo com seu grau de importância foram as seguintes: (1) clorofila a; (2) clorofila b; (3) clorofila total e (4) proteínas solúveis totais.

Ao observamos a figura 14 , notamos que a distribuição dos tratamentos ao longo dos eixos na primeira semana foi totalmente aleatória, entretanto, o tratamento $\mathrm{T}_{3}\left(5 \mathrm{mmol} . \mathrm{L}^{-1}\right.$ de $\mathrm{Ca}^{2+}$ suplementar $)$ foi o que mais se aproximou do controle. 


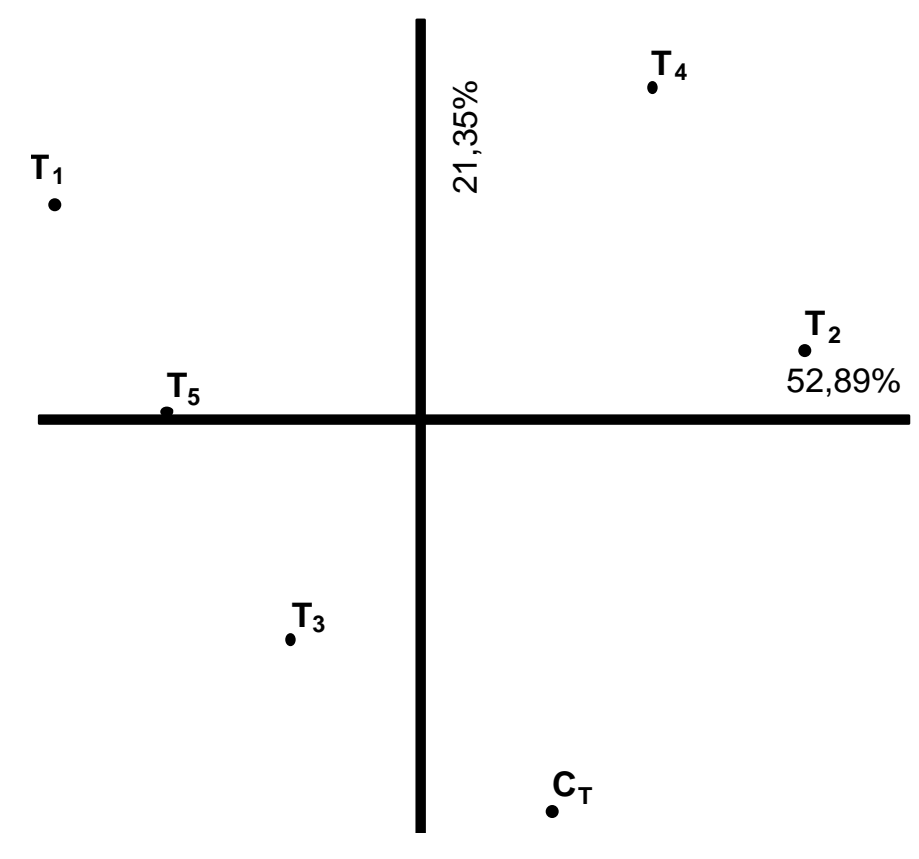

Figura 14 - Análise de componentes principais após 7 dias sob condições de estresse hídrico induzido por PEG 15\%.

A ordenação dos tratamentos ao longo dos eixos ao final do período $\left(21^{\circ}\right.$ dia) sob condições de deficit hídrico induzido por PEG 6000 a $15 \%$ demonstrou que o eixo 1 explicou $61,92 \%$ dos dados. O componente principal 2 (eixo 2), explicou $16,65 \%$ da distribuição espacial dos dados. Somados os dois eixos perfazem $78,57 \%$ da distribuição geral dos dados (figura 15).

A distribuição dos tratamentos ao longo dos dois eixos ao final do período de estresse hídrico foi marcado pela formação de dois grupos distintos: grupo 1, onde se encontram os tratamentos $T_{1} ; T_{3}$ e $T_{5}$, e grupo 2 , composto pelos tratamentos $\mathrm{T}_{2}$ e $\mathrm{T}_{4}$ (Figura 15).

Essa correlação de dados demonstrou que ao final do período sob estresse, as quatro primeiras variáveis a contribuírem para esse padrão de distribuição de acordo com seu grau de importância foram as seguintes: (1) 
proteínas solúveis; (2) prolina; (3) açúcares solúveis totais e (4) aminoácidos solúveis totais.

O tratamento controle manteve-se totalmente isolado em relação aos dois grupos estabelecidos ao final do período de estresse (Figura 15).

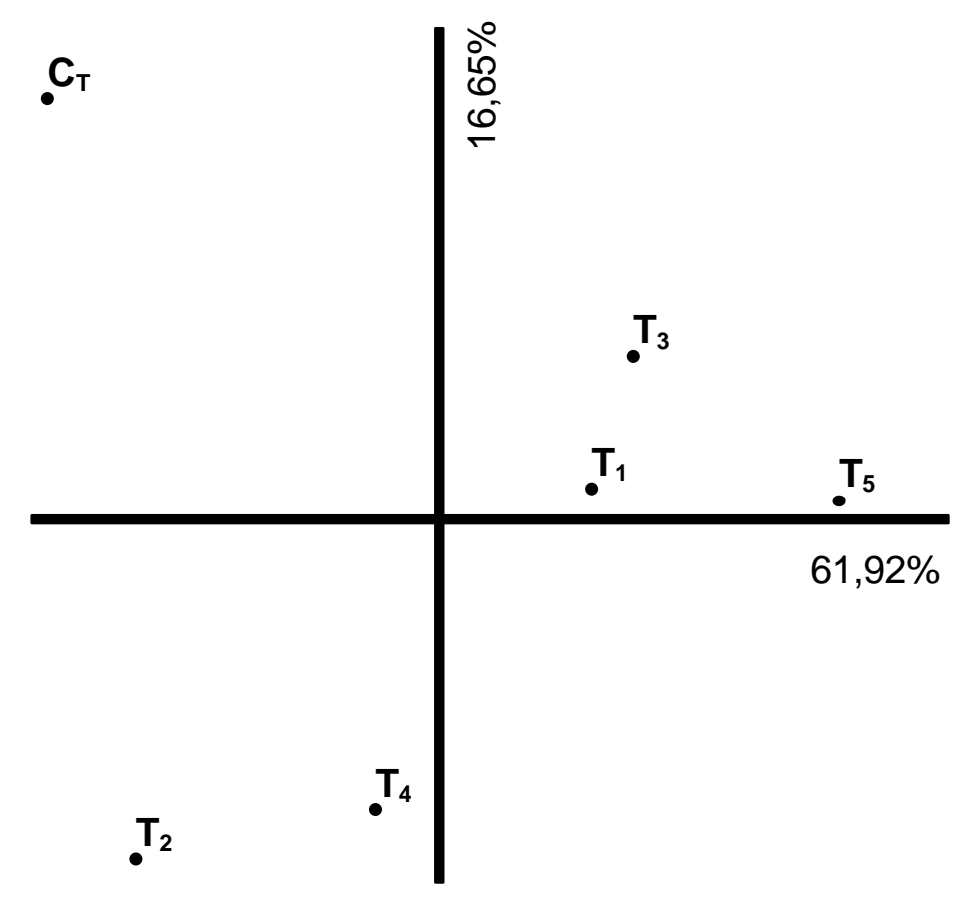

Figura 15 - Análise de componentes principais após 21 dias sob condições de estresse hídrico induzido por PEG 15\%

A ordenação dos tratamentos ao longo dos eixos ao final do período de recuperação sob condições de crescimento normal (Meio JADS líquido) demonstrou que o eixo 1 explicou $59,61 \%$ dos dados. Já eixo 2, explicou 16,98\% da distribuição espacial dos dados. No total, os dois eixos totalizam $76,59 \%$ da distribuição geral dos dados.

Essa correlação de dados demonstrou que ao final do período de recuperação $\left(21^{\circ} \mathrm{dia}\right)$, as quatro primeiras variáveis a contribuírem para esse padrão de distribuição de acordo com seu grau de importância foram as 
seguintes: (1) Aminoácidos solúveis totais; (2) prolina; (3) açúcares solúveis totais e (4) proteínas solúveis totais.

Ao observamos a figura 16, notamos claramente que o tratamento $T_{2}$ (2,5 mmol.L $\mathrm{L}^{-1}$ de $\mathrm{Ca}^{2+}$ suplementar) aproximou-se ao tratamento controle

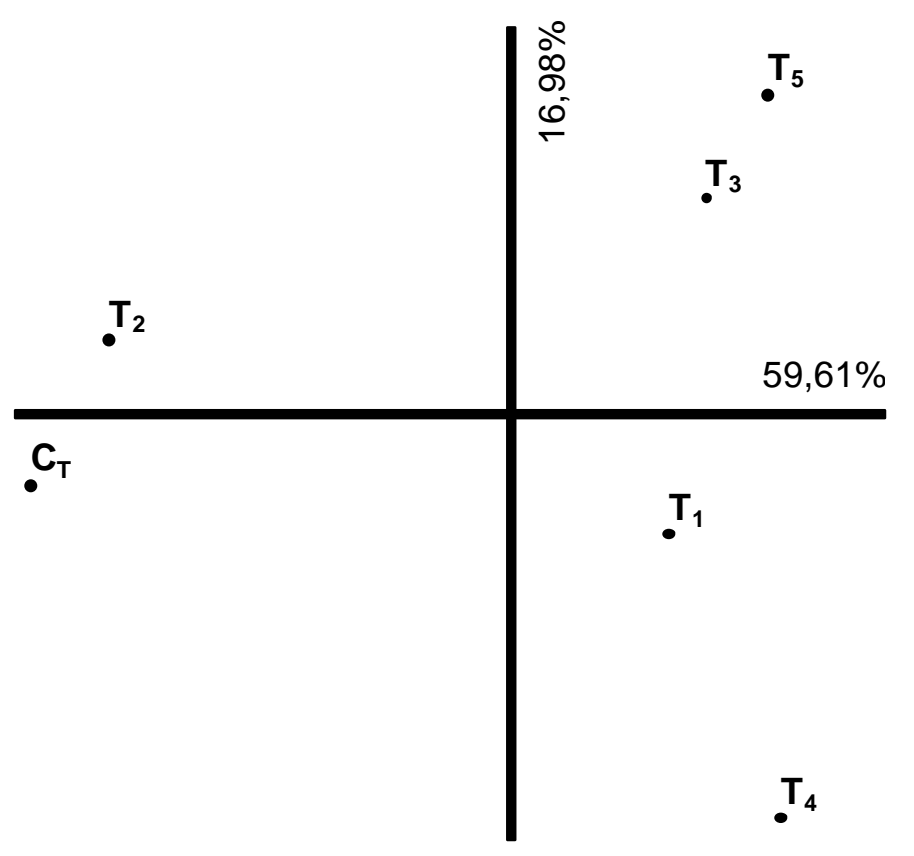

Figura 16 - Análise de componentes principais 21 dias após o retorno do material às condições normais de crescimento (JADS básico) - Recuperação "recovery".

Os resultados obtidos demonstraram que brotações de E. grandis submetidas a condições de deficiência hídrica por PEG 10\% e 15\% in vitro, não apresentaram um padrão explícito de resposta em função de doses crescentes de $\mathrm{Ca}^{2+}$ (5 a 15 mmol. $\left.\mathrm{L}^{-1}\right) \backslash$. De qualquer forma, o $\mathrm{Ca}^{2+}$ parece contribuir para a estabilidade no sistema de acordo com alguns dos parâmetros analisados: Prolina, açúcares e Aminoácidos solúveis, principalmente em relação a concentração de 2,5 mmol.L-1 de $\mathrm{Ca}^{2+}$ fornecida ao meio de cultura JADS líquido. 


\section{CONCLUSÕES}

Com base nos resultados podemos concluir que o cálcio atua como atenuador nos danos causados pelo estresse hídrico. As análises do potencial hídrico foliar realizadas ao longo dos períodos sugeriram que o PEG à 15\% induziu à deficiência hídrica nos tecidos de Eucalyptus grandis, com indicaram os valores de potencial hídrico foliar $\left(\psi_{\mathrm{f}}\right)$.

As análises de PCA indicaram que a dose de cálcio de 2,5 mmol. $\mathrm{L}^{-1}$ $\left(T_{2}\right)$ adicionada ao meio de cultura JADS foi mais eficaz na tolerância à deficiência hídrica e capacidade homeostatica.

Embora não fossem observadas alterações na produção de material vegetal seco (Taxa de crescimento relativo), o nível de deficiência hídrica testada neste trabalho foi suficiente para desencadear um processo de ajuste osmótico, principalmente pelo aumento do conteúdo de prolina, aminoácidos e açúcares.

Desta maneira, as análises bioquímicas, principalmente aminoácidos solúveis e açúcares solúveis, foram mais sensíveis na detecção do estresse hídrico induzido em relação às histológicas. 


\section{REFERÊNCIAS BIBLIOGRÁFICAS}

ABDEL-BASSET, R. Calcium channels and membrane disorders induced by drought stress in Vicia faba plants supplemented with calcium. Acta Physiologiae Plantarum, v.20, n.2, p.149-153, 1998. /Resumo CAB Abstracts, 1998/08 - 1999/07/

ALBERTS, B.; BRAY, D; LEWIS, J; RAFF, M. et al. Biologia molecular da célula. 3.ed. Porto Alegre: Artes Médicas. 1997. 1294p.

ALFOCEA, F. P.; LARHER, R. Sucrose and proline accumulation and sugar efflux in tomato leaf discs affected by $\mathrm{NaCl}$ and polyethylene glycol 6000 iso-osmotic stress. Plant Science, v.107, p.9-15, 1995.

ARORA, S.; SARADHI, P. Light-induced enhancement in proline levels in Vigna radiata exposed to environmental stress. Australian Journal of Plant Physiology, v.22, p.383-386, 1995.

BALLESTER-FERNANDEZ, G.; CERDÁ, G.; MARTÍNEZ, V. Role of calcium short-term responses of bean plants to osmotic or saline shocks. Journal of Plant Physiology, v.151, p.741-747, 1997.

BARROS, N. F; NOVAIS, R. F.; CARDOSO, J. R. et al. Relação planta solo. Viçosa: Editora da Universidade Federal de Viçosa, 1990. 325p.

BATES, L. S.; WALDREN, R. P. E.; TEARE, I. D. Rapid determination of free proline for water-stress studies. Plant and Soil, v.39, p. 205-207, 1973. 
BELL, D. T.; McCOMB, J. A.; MOEZEL, P. G. van der et al. Comparisons of selected and cloned plantlet against seedlings for rehabilitations of saline and waterlogged discharge zones in Australian agricultural catchments. Australian Forest, v.57, p.69-75, 1994.

BENYON, R. Managing water to arrest environmental degradation and enhance productivity. In: NAMBIAR, S.; CROMER, R.; BROWN, A. (Ed.). Restoring tree cover in the Murray-Darling Basin. Camberra: CSIRO Forestry and Forest Products, 2000. cap.6, p.27-31.

BERGMANN, W. (Ed.) Nutritional disordens of plants: development, visual and analytical diagnosis. New York: Jenna Stuttgart, 1992. cap.4, p.86-331: Causes, development, and diagnosis of symptoms resulting from mineral element dificiency and excesso.

BORSANI, O.; DÍAZ, P.; MONZA, J. Proline is involved in water stress responses of Lotus corniculatus nitrogen fixing and nitrate fed plants. Journal of Plant Physiology, v. 155, p.269-273, 1999.

BRADFORD, M. M. A rapid na sensitive method for the quantitation of microgram quantities of protein utilizing the principle of protein-dye binding. Analytical Biochemistry, v.72, p.248-254, 1976.

BURGIÉRE, N.; DUBOIS, F.; LIMAMI, A. M.; LELANDAIS, M. et al. Glutamine synthetase in the phloem plays a major role in controlling proline production. The Plant Cell, v.11, p.1995-2011, 1999.

CAMARGO, A. F. de. Matéria seca, concentração e conteúdo de macronutrientes em mudas de clones de eucalipto, em função da idade. Piracicaba, 1997. 94p. Dissertação (Mestrado) - Escola Superior de Agricultura "Luiz de Queiróz", Universidade de São Paulo. 
CORREIA, D. Crescimento e desenvolvimento de gemas na multiplicação de Eucalyptus spp. "in vitro" em meio de cultura líquido e sólido. Piracicaba, 1993. 139p. Dissertação (Mestrado) - Escola Superior de Agricultura "Luiz de Queiróz", Universidade de São Paulo.

CUTTER, E. G. Anatomia vegetal. 2.ed. São Paulo: Roca,1986. v.2, Órgãos, $336 p$.

DELAUNEY, A. J.; VERMA D. P. S. Proline biosynthesis and osmorregulation in plants. The Plant Journal, v.70, p.207-211, 1993.

DYE, P. J. Response of Eucalyptus grandis trees to soil water deficits. Tree Physiology, v. 16, p.233-238, 1996.

ELDRIDGE K.; DAVIDSON, J.; HARWOOD, C. et al. Eucalypt domestication and breeding. Oxford: Clarendon Press, 1994. 288p.

EVANS, J. Plantation forestry in the tropics. Oxford: Calendon Press, 1993. 403p.

FEIJO, J. A.; MALHO, R.; OBERMEYER, G. Ion dynamics and its possible role during in vitro pollen germination and tube growth. Protoplasma, v.187, p.155-167, 1995.

FERREIRA, C. A.; DAVIDA, A. C.; CARAVALHO, L. R. de. Relações hídricas em mudas de Eucalyptus citriodora Hook.; em tubetes aclimatadas por tratamentos hídricos. Cerne, v.5, p.95-104, 1999.

FLORENCE, R. G. The biology of the eucalypt forest. In: PATE, J.S.; McCOMB, A. M. (Ed.) The biology of Australian plants. Camberra: University of Western Australia Press, 1981. cap.5, p. 147-180.

GHOLZ, H.L.; EWEL, K. C.; TESKEY, R. O. Water and forest productivity. Forest Ecology and Management, v.30, p.1-18, 1990. 
GOES, E. Ecologia: cultura e produções. Lisboa: Ministério da Economia, 1962. Os eucaliptos em Portugal. p.47-58: v.2.

GOLFARI, L.; CASER, R. L.; MOURA, V. P. G. Zoneamento ecológico esquemático para reflorestamento no Brasil. In: PROJETO DE DESENVOLVIMENTO E PESQUISA FLORESTAL. PRODEPEF. Piracicaba, 1978. p.1-66 (Série Técnica).

GONÇALVES, J. L. M. Recomendações de adubação para Eucalyptus, Pinus e espécies típicas da mata Atlântica. Documentos Florestais, v.15, p.123, 1995.

HALE, M. G.; ORCUTT, D. M. The physiology of plants under stress. New York: John Wiley, 1987. 205p.

HARE, P. D.; CRESS, W. A.; STADEN, J. van. Proline synthesis and degradation: a model system for elucidating stress-related signal transduction. Journal of Experimental Botany, v.50, p.413-434, 1999.

HASEGAWA, P. M. BRESSAN, R. A; HANDA, S. et al. Cellular mechanisms of tolerance to water stress. HortScience, v. 19, p. 371-377, 1984.

HAYASHI, F.; ICHINO, T.; OSANAI, M. et al. Oscillation and regulation of proline content by P5CS and ProDH gene expressions in the light/dark cycles in Arabidopsis thaliana L. Plant Cell Physiology, v.41, p.1096-1101, 2000.

HENDRY, G. A. F.; GRIMES, J. P. (Ed.) Methods in comparative plant ecology: a laboratory manual. London: Chapman \& Hall, 1993. 252p.

HEPLER, P. K.; WAYNE, R. O. Calcium and plant development. Annual Review of Plant Physiology, v.36, p.397-439, 1985.

HONEYSETT, J. L.; WHITE, D. A.; WORLEDGE, D. et al. Growth and water use of Eucalyptus globulus and E. nitens in irrigated and rainfed plantations Australian Forest, v.59, p.64-73, 1996. 
HONG, Z.; LAKKINENI, K.; ZHANG. et al. Removal of feedback inhibition of $\Delta^{1}$ Pyrroline-5-carboxylate syntetase results in increased proline accumulation and protection of plants from osmotic stress. Plant Physiology, v.122, p.1129-1136, 2000.

HSIAO, T.; ACEDO, E.; FERERES, E. et al. Stress metabolism: water stress, growth and osmotic adjustment. Philosophical Transactions of Royal Society of London, v.273, p.479-500, 1976.

HUNT, R. Plant growth curves: the functional approach to plant growth analysis. London: Edward Arnold, 1982. 248p.

JACOBS, M. R. Growth habits of the eucalypts forestand timber boreau. Camberra: Commonwealth of Australia, 1955. 262p.

JONES, H. G.; JONES, M. B. Introduction: some terminology and commom mechanisms. In: JONES, H. G.; FLOWERS, T. J.; JONES, M. B. (Ed.) Plants under stress. Cambridge: Cambridge University Press, 1992. cap.1, p. 110. (Society for Experimental Biology. Seminar Series, 39)

KARNORVSKY, M. J. A formaldehyde-glutaraldehyde fixative of high osmolality for use in electron microscopy. Journal of Cell Biology, v.27, p.137-138, 1965.

KAUFFMAN, S. A. The orginis of order. New York: Oxford University Press, 1993. 709p.

KAWASAKI, S.; MIYAKE, C.; KOKCHI, T. et al. Responses of wild watermelon to drought stress: accumulation of an ArgE homologue and citrulline in leaves during water deficits. Plant Cell Physiology, v.41, p.864-873, 2000.

KNIGHT, H.; BRANDT, S.; KNIGHT, M. R. A history of alters drought calcium signalling pathways in Arabidopsis. The Plant Journal, v.16, n.6, p.681-687, 1998. 
KNIGHT, H.; TREWAVAS, A. J.; KNIGHT, M. R. Calcium signalling in Arabidopsis thaliana responding to drought and salinity. Journal of Plant, v.199, p.10671078, 1997

LANGER, M. Estudos e análises dos efeitos do cálcio sobre o crescimento inicial do híbrido de Eucalyptus urophylla x Eucalyptus grandis in vitro. Piracicaba, 2000. 101p. Dissertação (Mestrado) - Escola Superior de Agricultura "Luiz de Queiroz", Universidade de São Paulo.

LARCHER, W. Ecofisiologia vegetal. São Carlos: RiMa, 2000. cap.6, p.341448: A planta sob estresse.

LARHER, F.; LEPORT, L.; PETRIVALSKY, M. et al. Effectors for the osmoinduced proline response in higher plants. Plant Physiology Biochemistry, v.31, p.911-992, 1993.

LEE, TSE-MIN.; LIU, C. H. Correlation of decreased calcium contents with proline accumulation in the marine green macroalga Ulva fasciata exposed to elevated $\mathrm{NaCl}$ contents in seawater. Journal of Experimental Botany, v.50, p.1855-1862, 1999.

LELES, P. S. S.; REIS, G. G. dos; REIS, M.G. F. et al. Relações hídricas de Eucalyptus camaldulensis e E. pellita na região de cerrado. In: IUFRO CONFERENCE ON SILVICULTURE AND IMPROVEMENT OF EUCALYPTUS/CONFERÊNCIA IUFRO SOBRE SILVICULTURA E MELHORAMENTO DE EUCALIPTOS, Salvador, 1997. Proceedings. Colombo: EMBRAPA, 1997. p.201-206.

LEVITT, J. Physiological ecology: a series of monographs, texts, and treatises. New York: Academic Press, 1972. cap.13, p.322-346: Water deficit (or drought) stress. 
LIMA, P.C; BARROS, N. F.; REIS, G. G. dos et al. Alterações morfológicas, fisiológicas e partição de matéria seca em mudas de Eucalyptus ssp submetidas a deficiência hídrica no solo. In: IUFRO CONFERENCE ON SILVICULTURE AND IMPROVEMENT OF EUCALYPTUS/ CONFERÊNCIA IUFRO SOBRE SILVICULTURA E MELHORAMENTO DE EUCALIPTOS, Salvador, 1997. Proceedings. Colombo: EMBRAPA, 1997. p.30-37.

LIMA, W. P. Impactos da cultura do eucalipto. Silvicultura, v.16, p.32-38, 1995.

LIMA, W. P. Impacto ambiental do eucalipto. São Paulo: EDUSP, 1996. $301 \mathrm{p}$.

MALAVOLTA, E. Avaliação do estado nutricional das plantas: princípios e aplicações. Piracicaba: Potafos, 1997. cap.5, p.55-114: Funções.

MALHÓ, R.; MOUTINHO, A.; van der LUIT, A. et al. Spatial characteristics of calcium signalling: the calcium wave as a basic unit in plant cell calcium signalling. Philosophical Transactions of Royal Society of London, v.353, p.1463-1473, 1998.

MALHÓ, R.; TREWAVAS, A. Localized apical increases of cytosolic free calcium control pollen tube orientation. Plant Cell, v.8, p.1935-1949, 1996.

MARMÉ, D. The role of calcium in the regulation of plant cellular metabolism. In: GERDAY, Ch.; GILLES, R.; BOLIS, L. (Ed.) Calcium and calcium binding proteins. Berlin: Spring-Verlag, 1988. p.201-208.

MASCARENHAS, H. A. A. Cálcio, enxofre e ferro no solo e na planta. Campinas: Fundação Cargill, 1977. 95p.

MATOH, T.; WATANABE, J.; TAKAHASHI. Sodium, potassium, chloride, and betaine concentrations in isolated vacuoles from salt-grown betaine concentrations in isolated vacuoles from salt-grow Atriplex gmelini leaves. Plant Physiology, v.84, p.173-177, 1987. 
MENGEL, K.; KIRKBY, E. A.. Principles of plant nutrition. 4.ed. Bern: International Potash Institute, 1982 cap.11, p.455-480: Calcium.

MORAN J.; BECANA, M.; ITURBE-ORAETXE I. et al. Drought induces oxidative stress in pea plants. Planta, v.194, 346-352, 1994.

MOURA, A. L.; GARCIA, C. H. A cultura do eucalipto no Brasil. São Paulo: SBS, 2000. 112p.

MUNNS, R. Why measure osmotic adjustment? Australian Journal of Plant Physiology, v.15, p.717-726, 1988.

NAMBIAR, E. K.S. Management of forests under nutrient and water stress. Water, Air, and Soil Pollution, v.54, n.2, p.209-230, 1990/91.

NePOMUCenO, A. L.; OOSTERHUIS, D. M.; STEWART, J. M. Physiological responses of cotton leaves and roots to water deficit induced by polyethylene glycol. Environmental and Experimental Botany, v.40, p.29-41, 1998.

OSÓRIO, J.; OSÓRIO, M. L.; CHAVES, M. M. et al. Water deficits are more important in delaying growth than in changing patterns of carbon allocation in Eucalyptus globulus. Tree Physiology, v.18, p.363-373, 1998.

PASSOS, L. P. Métodos analíticos e laboratoriais em fisiologia vegetal. Coronel Pacheco: EMBRAPA, CNPGL, 1996. 223p.

PATAKAS, A.; NOITSAKIS, B. Leaf age effects on solute accumulation in waterstress grapevines. Journal of Plant Physiology, v.158, p.63-69, 2001.

PELAH, D.; WANG, W.; ALTMAN, A. et al. Differential accumulation of water stress-related proteins, sucrose synthase and soluble sugars in Populus species that differ in their water stress response. Physiologia Plantarum, v.99, p.153-159, 1997. 
POORE, M. E. D.; FRIES, C. The ecological effects of Eucalyptus,. Rome: FAO, 1985. 87p. (FAO. Forestry Paper).

POOVAIAH, B. W.; REDDY, A.S.N. calcium messenger system in plants. CRC in Plant Science, v.6, p.70-72, 1975.

PORRA, R. J.; THOMPSON, W. A.; KRIEDEMANN, P. E. Determination of accurate extinction coefficients and simultaneous equations for assaying chlorophylls $a$ and $b$ extracted with four different solvents: verifications of the concentration of chlorophyll standards by atomic absorption spectroscopy. Biochimica et Biophysica Acta, v.975, p.384-394, 1989.

PRYOR, L. D. The biology of eucalypts. London: Edward Arnold, 1976. 80p. (The Institute of Biology. Studies in Biology, 61).

RAMALHO, J. C.; NUNES, M. A. Photosynthesis impairment in Coffea arabica due to calcium deficiency. Agronomia Lusitana, v.47, p.101-116, 1999.

RAMALHO, J. C.; REBELO, M. C. SANTOS, M. E. et al. Effects of calcium deficiency on Coffea arabica. Nutrient changes and correlation of calcium levels with some photosynthetic parameters. Plant and Soil, v, 172, p.8796, 1995.

REDDY, A. S. N. Calcium: silver bullet in signaling. Plant Science, v.160, p.381-404, 2001.

REIS, G. G. dos; HALL, A. E. Respostas de brotações de Eucalyptus camaldulensis Dehn. submetidas a diferentes níveis de deficiência hídrica. Revista Árvore, v.10, p.16-26, 1986.

RHODES, D. Metabolic responses to stress. In: STUMPF, P. K.; CONN, E. E. The biochemistry of plants. New York: Academic Press, 1987. cap.12, p.201-241. 
SAKAI, W. S. Simple method for differential staining of paraffin embedded plant material using toluidine blue O. Stain Technology, v.48, n.5, p.247-249, 1973.

SANDERS, D.; BROWNLEE, C.; HARPER, J. F. Communicating with calcium. The Plant Cell, v.11, p.691-706, 1999.

SAVOURÉ, A.; JAOUA, S.; HUA, X. J.; ARDILES, W. et al. Isolation, characterization, and chromosomal location of a gene encoding the DELTA1-pyrroline-5-carboxylate synthetase in Arabidopsis thaliana. FEBS letters, v.372, p.13-19, 1995.

SCHURR, U.; HECKENBERGER, U.; HERDE, K. et al. Leaf development in Ricinus communis during drought stress: dinamics of growth processes, of cellular structure and of sink-source transition. Journal of Experimental Botany, v.51, p.1515-1529, 2000.

SOUZA, G. M.; GONÇALVES, A. N; ALMEIDA, M. de. Water deficit relation to leaf and stem anatomy of Eucalyptus camaldulensis Dehn. shoots cultivated in vitro. Scientia Agricola, v.56, n.3, p.723-731, 1999.

STEWART, C. R. Role of carbohydrates in proline accumulation in wilted barley leaves. Plant Physiology, v.61, p. 775-778, 1978

STEWART, C. R.; FARHER, L. Accumulation of amino acids and related compounds in relation to environmental stress. In: STUMPF, P. K.; CONN, E. E. The plant biochemistry. New York: Academic Press, 1980. v. 5, p.609635.

STEWART, C. R.; MORRIS, C. J.; THOMPSOM, J. F. Changes in aminoacid content of excised leaves during incubation II. Role of sugar in the accumulation in wilted barley leaves. Plant Physiology, v. 41, p.1585-1590, 1966. 
STINES, A. P.; NAYLOR, D. J.; HØJ, P.B. et al. Proline accumulation in developing grapevine fruit occurs independently of changes in the levels of $\Delta^{1}$-Pyrroline-5-carboxylate syntetase mRNA or protein. Plant Physiology, v.120, p.923-931, 1999.

TAKEDA, T.; KITAGAWA, T.; TAKEUCHI, Y. et al. Metabolic responses of plant cell culture to hydrodynamic stress. Canadian Journal of Chemical Engineering. v.76, p.267-275, 1998.

TREWAVAS, A.; KNIGHT, M. Mechanical signalling, calcium and plant form. Plant Molecular Biology, v.26, p.1329-1341, 1994.

TURNER, N. C. Adaptation to water deficits: a changing perspective. Australian Journal of Plant Physiology, v.13, n.1, p.175-190, 1986.

WITHERS, J. R. Studies on the status of unburnt Eucalyptus woodland ocean grove, Victoria. III - Comparative water relations of the major tree species. Australian Journal of Botany, v.26, p.819-825, 1978.

YEMM, E. W.; WILLIS, A. J. The estimation of carbohydrates in plant extracts by anthrone. The Biochemical Journal, v.57, p.508-515, 1954.

ZERKI, M. PEG stress altered citrus root and leaf mineral concentrations. Journal of Plant Nutrition, v.18, n.6, p.1087-1102, 1995.

ZHANG, C. S.; LU, Q.; VERMA, D. P. S. Characterization of pyrroline-5carboxylato synthetase gene promoter in transgenic Arabidopsis thaliana subjected to water stress. Plant Science, v.129, p.81-89, 1997.

ZHU, J. K.; HASEGAWA, P. M. E.; BRESSAS, R. A. Molecular aspects of osmotic stress in plants. Critical Reviews in Plan Sciences, v.16, p.253$277,1997$. 